Atmos. Chem. Phys., 10, 5089-5105, 2010

www.atmos-chem-phys.net/10/5089/2010/

doi:10.5194/acp-10-5089-2010

(C) Author(s) 2010. CC Attribution 3.0 License.

\title{
Origin and transport of Mediterranean moisture and air
}

\author{
I. Schicker, S. Radanovics, and P. Seibert \\ Institute of Meteorology, University of Natural Resources and Applied Life Sciences, Vienna, Austria
}

Received: 9 September 2009 - Published in Atmos. Chem. Phys. Discuss.: 12 October 2009

Revised: 19 April 2010 - Accepted: 25 May 2010 - Published: 8 June 2010

\begin{abstract}
Considering the Mediterranean as a region of high evaporation and low precipitation, evaluations of sinks and sources of moisture and precipitation in the Mediterranean basin have been carried out within the frame of the CIRCE (Climate Change and Impact Research: the Mediterranean Environment) project. Besides these evaluations, residence time and stagnation/ventilation analyses have been carried out to investigate transport to and from the Mediterranean basin and in the basin itself. A Lagrangian moisture diagnosis method calculating budgets of evaporation minus precipitation was applied to a 5.5 year (October 1999April 2005) trajectory data set and evaluated for eight representative Mediterranean Regions Of Interest (ROI). The Mediterranean basin has been identified as a major source of moisture and precipitation to the surrounding land area and to the basin itself. Main regions of stagnation, i.e. the Po basin, have been defined on a seasonal basis through residence time analysis. Evaluation of the transport to and from the basin shows that the Mediterranean is a crossroad of airstreams where air enters mainly from the northwest and continues in two separate streams, one going southwest over North Africa into the trade wind zone and the other one to the northeast through Central Asia.
\end{abstract}

\section{Introduction}

\subsection{Motivation}

The Mediterranean region has been identified as one of the "hot spots" for present and future climate change (Giorgi, 2006; Gibelin and Deque, 2003). This high sensitivity to climate change is a consequence of the fact that its weather is

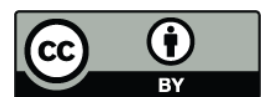

Correspondence to: I. Schicker

(irene.schicker@boku.ac.at) dominated by the midlatitude westerlies in the moist winters, and the subtropical high in the hot and dry summers, being influenced also by the trade winds and the Asian and African monsoons (e.g., Alpert et al., 2006; Luterbacher and Xoplaki, 2003; Xoplaki et al., 2003, and references therein). There are significant effects from the Mediterranean itself on the adjacent regions, e.g. the moisture flux into Northern Africa (Ward, 1998; Mariotti et al., 2002) or into the Alpine region (Sodemann and Zubler, 2010). Especially on the southern side of the Alps, flows from the Mediterranean are associated with precipitation and are the main cause of extreme events. During the summer season, stagnation and recirculation are common and contribute to accumulation of air pollutants, especially ozone (Millán et al., 1996, 1997).

On this background, several large research programmes have been launched, such as MedClivar ${ }^{1}$ (Mediterranean CLImate VARiability and Predictability) (Lionello et al., 2006), HyMeX ${ }^{2}$ (HYdrological cycle in the Mediterranean EXperiment) (Drobinski and Ducrocq, 2008), and CIRCE ${ }^{3}$ (Climate Change and Impact Research: the Mediterranean Environment). This study is a part of CIRCE and aims at clarifying in a quantitative way budgets of air and moisture in the Mediterranean and its sub-basins. The transport and residence times of air masses are related both to moisture and air pollution budgets; the moisture budgets are considered explicitly here as we have detailed information about them through the ECMWF data.

The transport patterns affecting the Mediterranean region were studied with Lagrangian methods both with a sourceoriented and a receptor-oriented view, based on the data set of Stohl (2006). The fate of air masses passing over the regions of interest as well as their previous history has been investigated. In addition, residence times and analyses of stagnation

\footnotetext{
${ }^{1}$ http://www.medclivar.eu/

${ }^{2}$ http://www.cnrm.meteo.fr/hymex/

${ }^{3}$ http://www.circeproject.eu/
}

Published by Copernicus Publications on behalf of the European Geosciences Union. 
versus ventilation have been carried out. The moisture has been handled in a similar way, identifying the fractions of atmospheric moisture and of precipitation originating from the Mediterranean basin or, respectively, selected sub-basins. Vertically integrated mean fluxes of moisture orginating from the Mediterranean are also shown.

\subsection{Related existing work}

Transport of air masses (e.g. pollutants and moisture) significantly influences air pollution (Newell and Evans, 2000; Stohl et al., 2002) and the fraction of atmospheric water vapour in a region (Newell et al., 1992; Zhu and Newell, 1998). The Mediterranean basin has been one focus region of long-range transport studies, inter alia the MINOS (Mediterranean intensive oxidant study) campaign (Mihalopoulos and de Reus, 2003), the MECAPIP (Millán et al., 1992, 1996, 1997; Salvador et al., 1997) project, the SECAP (Millán et al., 1997) project, or the SUB-AREO (Lazaridis et al., 2006); for more information on transport studies in the Mediterranean see Kallos et al. (2007). These studies investigated complicated flow patterns associated with mountainous topography, land-sea circulations, recirculation patterns, and the interaction between the marine boundary layer and the atmospheric boundary layer on the transport of air pollutants, and characterised the prevailing conditions in the Mediterranean basin. Also, teleconnection modes such as the North Atlantic oscillation (Hurrell, 1995, 1996; Rodo et al., 1997; Krichak et al., 2002; Krichak and Alpert, 2005; Mariotti et al., 2002), the position of the jet stream, and the pressure difference between Azores high-pressure system and the Persian trough during the warm season (Millán et al., 1997; Kallos et al., 1998, 2007) affect transport of clean and polluted air masses (e.g. Millán et al., 1997; Kallos et al., 2007) in the Mediterranean region and Europe. These teleconnections have effect both on the air pollution transport and rainfall anomalies in the Mediterranean (Eshel and Farrel, 2000).

Within the MINOS campaign (Lelieveld et al., 2002) and the SECAP project (Millán et al., 1997), different air mass trajectories, inflow and outflow, influencing the Mediterranean basin in the lower, middle and upper troposphere were identified. Observations during the MINOS study period (summer 2001) revealed that inflow from the North prevailed. These inflows were caused by a strong east-west pressure gradient between the Azorean high and the Asian monsoon low pressure system. In the free troposphere, the westerlies dominated in the Mediterranean basin. Additionally, inflow from Northwest and Southeast was found in the upper and middle troposphere (Lelieveld et al., 2002). In the lower troposphere, inflow from continental Europe into the Mediterranean prevailed (Lelieveld et al., 2002). Similar trajectories were found by Mariotti et al. (2002). They analysed the hydrological cycle in the Mediterranean for two periods, 1979-1993 and 1948-1998 using NCEP and ERA data, and compiled a climatology of atmospheric moisture flux and moisture divergence for the period 1979-1993.

An overview on observed and postulated atmospheric and regional circulations for different vertical levels in the Mediterranean basin in summer is given in Millán et al. (1997, Plate 5). In addition, Kallos et al. (2007, Fig. 4) and Astitha et al. (2008, Fig. 3) sketch pathways and their scales and levels of air mass transport in the Mediterranean region and its surroundings. Results of these studies already give a good overview on the different systems influencing the Mediterranean basin and provide a background for this paper and its results.

As noted before, sources and sinks of moisture and precipitation of a region has become a topic of interest, especially in context with heavy floodings, e.g., Central Europe in 2002 and 2005. Water in the atmosphere is important for the climate system in many ways, e.g. by modifying the Earth's radiation budget, and by the influence of precipitation on the thermohaline circulation (Weaver et al., 1999; Bethoux and Gentili, 1999).

Precipitation in a region may have, according to Brubaker et al. (1993), three kinds of origins: moisture already present in the atmosphere, moisture advection, and evapo(transpi)ration from the surface below, the latter also referred to as recycling of precipitation (Eltahir and Bras, 1996). Large-scale moisture fluxes relevant for the advective contribution have been investigated by Newell et al. (1992) on a daily time scale, who identified "tropospheric rivers" associated with warm conveyor belts (see also Eckhardt et al., 2004). Zhu and Newell (1998) found that these tropospheric rivers account for nearly all the meridional water vapour transport in mid-latitudes.

Previous studies investigating the heavy flooding event in Central Europe in August 2002 were carried out by Stohl and James $(2004,2005)$ who used Lagrangian analysis to evaluate the surface freshwater flux $E-P$ using ECMWF data. They found out that the major moisture source region contributing to the precipitation event was the Mediterranean Sea. A climatological analysis of the precipitation, evaporation and moisture flux in the Mediterranean region for the past 50 years has been carried out by Mariotti et al. (2002) showing a positive mean of the budget $E-P$ over the Mediterranean Sea indicating that the atmosphere gains moisture from the Mediterranean.

\section{Method}

The Mediterranean basin is a region surrounded by mountain ridges in the North (Massif Centrale, Alps, Dinaric Mountains, Carparthians), West (Pyrenees, mountains of Iberian peninsula), East (Anatolian highlands) and parts of the South (Atlas Mountains). These mountains, and especially the gaps between them, lead to wind systems such as the mistral, the bora, the ponent, the scirocco and the etesians. The Italian 
peninsula (Appenine mountain range) and the Greek mountains divide the Mediterranean basin. A detailed meteorological and climatalogical explanation for the division of the Mediterranean basin into Western, Central, and Eastern Mediterranean basin is given in Millán et al. (2002). Millán et al. (1997) give a schematic summary of the circulations in the Mediterranean area, including orographic injections, recirculations, and channelling. To account for the influence of the different wind systems, the different circulations, the climatological background, and the topography, eight Regions Of Interest (ROI) were defined inside the Mediterranean basin (Fig. 1): one is the Mediterranean itself, then there are the three larger basins (1) Western Mediterranean, (2) Central Mediterranean, and (3) Eastern Mediterranean, and the four smaller basins (4) Adriatic Sea, (5) Balearics, (6) Aegean, and (7) the region between Cyprus and Israel.

Moisture and precipitation sources and sinks have been analysed using a Lagrangian particle dispersion data set produced by Stohl (2006). The model FLEXPART (Stohl et al., $1998,2005)$ was used in the global domain-filling mode to simulate a 5.5-year period starting on 27 October 1999 and ending on 1 May 2005. This period includes some extreme weather periods, especially the heavy floods in Central Europe in 2002 and the unusually hot and dry Summer 2003. Input data were the operational analyses at 00:00, 06:00, 12:00, and 18:00 UTC, and 3-h forecasts at intermediate times (03:00, 09:00, 15:00, 21:00 UTC) of the European Centre for Medium-Range Weather Forecast (ECMWF). A horizontal resolution of $1^{\circ} \times 1^{\circ}$ of the T319 model with 60 model levels was used. Approximately 14 levels are below $1500 \mathrm{~m}$, and 24 below $5000 \mathrm{~m}$. Trajectories were calculated using the interpolated mean winds from the input data plus random motions to account for turbulence.

At the start of the simulation 1398801 particles were released filling the atmosphere homogeneously. One of these particles represents about $3 \times 10^{12} \mathrm{~kg}$ of air. Particles move freely with the winds during the simulation. Output of particles' ID number, position (latitude, longitude, height above msl, height above ground), and interpolated meteorological parameters from the input analyses (temperature $T$, specific humidity $q$, air density $\rho$, atmospheric boundary layer (ABL) height and the tropopause height at the particles' position) were recorded every six hours.

Some limitations are implied by these data. The resolution of the meteorological input data of $1^{\circ}$ horizontally and $3 \mathrm{~h}$ temporally implies that mesoscale features are not resolved. The limited number of particles only allows an evaluation on seasonal base and for all the years together. Besides the accuracy of the trajectories, some small errors can be introduced in the calculation e.g. fluctuations of $q$ due to nonphysical reasons (interpolation errors) along individual trajectories which are partly compensated in an atmospheric column over a defined area and amongst a large number of particles for current $E-P$ (Stohl and James, 2004). Other limitations and restrictions of the method, especially regard-

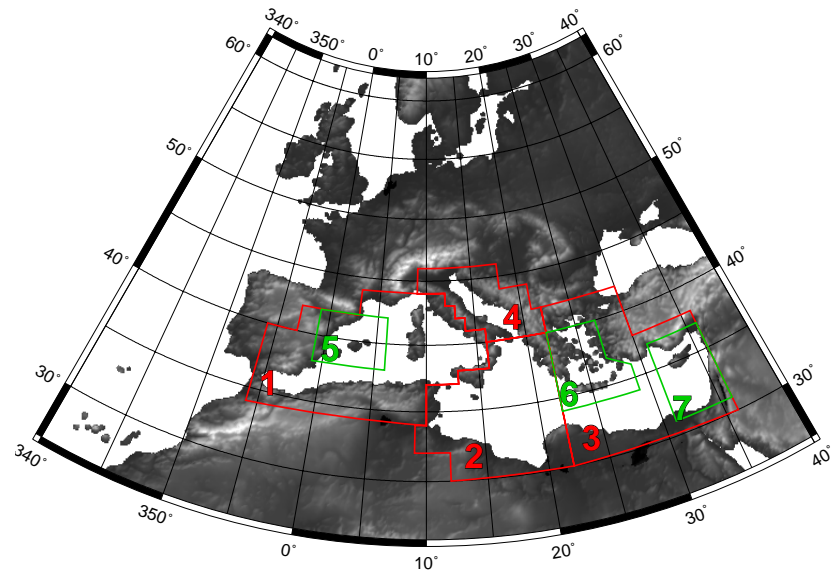

Fig. 1. Definition of the Mediterreanean basin and the seven subbasins. (1) Western Mediterranean, (2) Central Mediterranean, (3) Eastern Mediterranean, (4) Adriatic Sea, in red as they can be seen as natural boundaries, and (5) the Balearics, (6) the Aegean basin, and (7) the Cyprus basin in green as small, wind-influenced basins.

ing the moisture evaluations (see Sect. 3.3), are described in detail in Stohl and James (2004). We found that in a few rare cases specific humidity suddenly dropped from one time step to the next from plausible values to nearly zero specific humidity, probably indicating a bug in the FLEXPART data set. Linear interpolation has been used to replace buggy specific humidity values. As analyses for moisture flux, moisture and precipitation budgets, residence times, and a stagnation/ventilation index are averaged over a large period and large grid sizes, these effects can be neglected.

Results of all eight ROIs will be discussed, however, figures will be shown only for selected ROIs (see Seibert et al., 2009, and http://www.atmos-chem-phys.net/10/5089/2010/ acp-10-5089-2010-supplement.pdf for supplementary material.).

In the following, the definitions and calculation methods of the parameters are introduced.

\subsection{Residence time}

The residence time is defined as the average of the time spent by the simulated particles in the respective evaluation grid cell within the ROI and within the predefined time windows in this study. Residence times have been calculated in forward and backward mode for three different vertical layers: 0-1000 ma.g.l., whole troposphere, and the whole atmosphere, and four different transport times windows $\Delta t: 0-1$ days, $0-5$ days, $0-30$ days, and 0-90 days. The $0-1000$ ma.g.l. is a proxy for the ABL.

Residence times are shown on an annual basis only. The residence time is normalised with the number of particles in the ROI and $\Delta t$ in days, and is expressed in units of seconds per particle, receptor day, and grid cell. As grid cells are 
defined in a latitude-longitude grid, these values have been corrected to a standard grid cell size (as at the equator). Forward transport calculations show the fate of Mediterranean air, while backward calculations show the origin of air in the Mediterranean. Particles are counted in the forward mode if they resided initially in the ROI, in the backward mode if they arrived finally in the ROI. "Initially" and "finally" means within time windows $\Delta t$ as defined above.

High residence times indicate, on one hand, areas with stagnation, and on the other hand, transport pathways. Thus they are especially relevant for air pollution and moisture budgets.

\subsection{Stagnation/ventilation}

The residence times give already an idea of regions where the air stays a long time. Especially residence times with short time intervals are related to stagnant conditions. To show such areas more clearly, additional analyses for stagnation/ventilation have been carried out (see Allwine and Whiteman, 1994, for details of this concept). Ventilation/stagnation is defined as the vectorial mean of the particle velocities, or in other words, the distance between start point and end point of a particle divided by the length of the time interval. Low values indicate strong stagnation tendency, high values ventilation.

Stagnation has been calculated for the four seasons and different time intervals $\Delta t$ all over the globe. These time intervals are shorter than time intervals used for the residence times, namely one and five days. These are local parameters, not a relationship between a source (receptor) region and the rest of the world, thus it is not appropriate to do separate ROI calculations. Results are shown for the Mediterranean region only.

\subsection{Moisture budget and moisture flux}

Moisture source and sink tracking along the trajectories has been done using a method based on James et al. (2004); Stohl and James (2004, 2005), and Sodemann (2006); Sodemann et al. (2008a,b), also used by Nieto and Gimeno (2006); Nieto et al. $(2006,2007,2008)$ and Drumond et al. (2008).

The change in the moisture content $q$ of the air parcel $n$ in a time interval $\Delta t, \Delta q_{n} / \Delta t$, can be written as the balance of effects of evaporation $E$ minus precipitation $P$ :

$\frac{\Delta q_{n}}{\Delta t}=E-P$

Evaluations are carried out on a fixed 6-h time interval. Results of $\Delta q_{n}$ have units of $\mathrm{g} \mathrm{kg}^{-1}(6 \mathrm{~h})^{-1}$. The moisture change between two time steps is calculated as $\Delta q_{n}=$ $q_{n}(t)-q_{n}(t-1)$, where $q_{n}(t)$ is moisture at time $t$ and $q_{n}(t-1)$ is the moisture at the previous time step.

In order to distinguish between moisture originating inside and outside the ROIs, two different moisture variables are defined. We track moisture originating inside the ROIs, $q m_{n}$, with its changes between the timesteps, $\Delta q m_{n}$ and moisture originating outside the ROI, $q o_{n}$, with changes $\Delta q o_{n}$.

An increase of $q m_{n}$ is found if $\Delta q_{n}$ is positive and if the particle is inside the ROI, with

$\Delta q m_{n}=\Delta q_{n}$

where the moisture originating outside the ROI does not change:

$\Delta q o_{n}=0$.

If the particle is outside of the ROI, $\Delta q o_{n}=\Delta q_{n}$ and $\Delta q m_{n}=0$.

With a decrease of a particle's moisture between two timesteps (negative $\Delta q_{n}$ ), both $q m_{n}$ and $q o_{n}$ loose moisture pro-rata. In this case, $\Delta q m_{n}$ and $\Delta q o_{n}$ can be calculated as:

$$
\begin{aligned}
& \Delta q m_{n}=\frac{q m_{n}}{\left(q m_{n}+q o_{n}\right)} \Delta q_{n} \\
& \Delta q o_{n}=\frac{q o_{n}}{\left(q m_{n}+q o_{n}\right)} \Delta q_{n} .
\end{aligned}
$$

The fraction of the total moisture which evaporated inside the ROI, $q m_{i}(x, y)$, can be written as:

$q m_{i}(x, y)=\sum_{n} \frac{q m_{n}}{\left(q o_{n}+q m_{n}\right)}$

with

$q m_{n}=\sum_{n} \Delta q m_{n}$

and

$q o_{n}=\sum_{n} \Delta q o_{n}$

where $n$ are the particles in the gridbox. This fraction $q m_{i}(x, y)$ is then averaged over the seasons, and averaged over $1^{\circ} \times 1^{\circ}$ grid boxes. Note that each particle represents a defined, constant fraction of the total atmospheric mass, and density effects are represented by the particle density. Thus the air density does not appear in these equations.

In the ABL, moisture may change along a computational particle's trajectory by turbulent displacements in an environment that - according to the ECMWF input fields used by the original FLEXPART calculation and interpolations made therein - has a vertical specific moisture gradient without occurrence of evaporation or precipitation. Such effects would cause a too fast loss of Mediterranean moisture outside the ROI and of non-Mediterranean moisture inside the ROI. To counter this, the specific humidity of all particles inside the $\mathrm{ABL}$ is set to the average value over all the particles below ABL height and in the respective $1^{\circ} \times 1^{\circ}$ grid box. Furthermore, in the calculation of $\Delta q_{n}$, each specific humidity value is replaced by the average between the present and the previous time step. It should be noted that Mediterranean moisture may still decrease faster in the model than in reality and absolute values thus may be underestimated. 


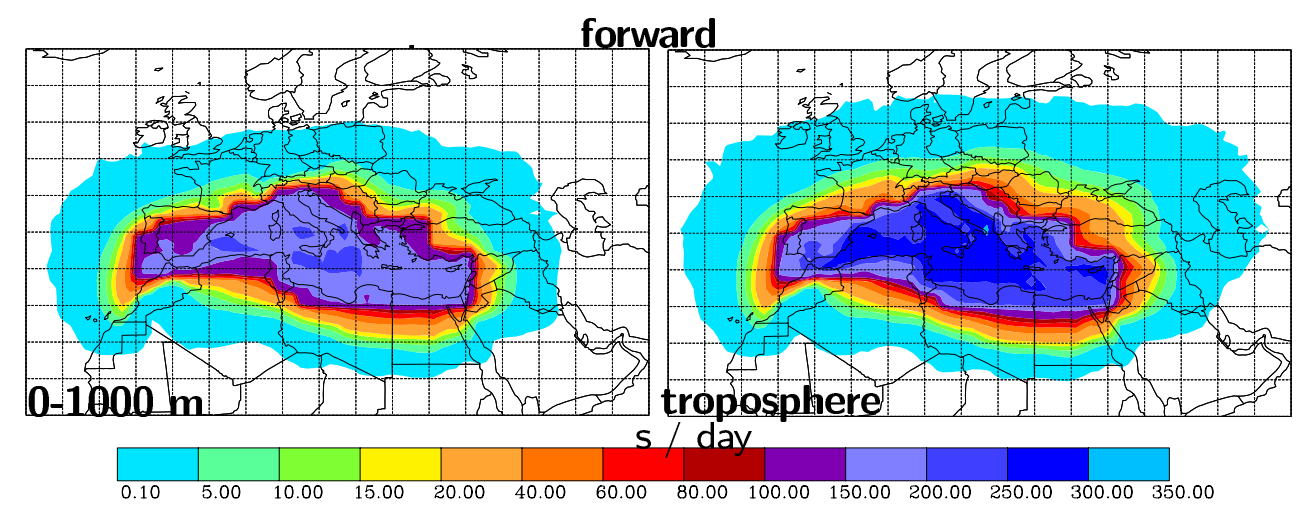

Fig. 2. One-day residence times in $\mathrm{s} / \mathrm{d}$ for the Mediterranean basin calculated for the lowest layer, 0-1000 $\mathrm{m}$ (left), and the whole troposphere (right) in forward mode.

In addition to the mixing ratio of the two kinds of moisture, vertically integrated horizontal fluxes of moisture $\boldsymbol{F}_{q}$ originating in the Mediterranean basin (Fig. 1) were calculated. The flux associated with a single particle is

$\boldsymbol{F}_{q n}=\boldsymbol{v}_{n} \overline{q m_{n}} M_{p}$

where the horizontal velocity vector $\boldsymbol{v}_{n}$ is taken from the particle displacement and

$\overline{q m_{n}}=q m_{n}(t-1)+\frac{q m_{n}(t)-q m_{n}(t-1)}{2}$.

The mass of air represented by each particle is the total atmosperic mass $\left(5.1 \times 10^{18} \mathrm{~kg}\right.$ divided by the total number of particles, i.e. $3.65 \times 10^{12} \mathrm{~kg}$ ). The gridded flux vector $\boldsymbol{F}_{q}$ is obtained by summing up all the $\boldsymbol{F}_{q n}$ in $1^{\circ} \times 1^{\circ}$ horizontal grid cells and vertically between 0 and $1000 \mathrm{~m}$ and between 0 and $20000 \mathrm{~m}$ a.g.l. divided by the area of the grid cell. It is thus expressed in units of $\mathrm{kg}\left(\mathrm{m} \mathrm{s}^{-1}\right.$, signifying the amount of Mediterranean moisture being transported across a line of $1 \mathrm{~m}$ length in $1 \mathrm{~s}$. Calculations were performed only with the whole Mediterranean basin as ROI.

\subsection{Precipitation budget}

The attribution of precipitation with respect to its origin in the ROIs was done in a way similar to the moisture calculations. The moisture changes inside and outside the ROI are evaluated and the moisture loss in the atmospheric column is considered as precipitation.

The fraction of the precipitation $p m_{i}(x, y)$ which contains water evaporated in the ROI is calculated similarly to the moisture fraction $q m_{i}(x, y)$, but instead of $q m_{n}$ and $q o_{n}$, the quantities $\Delta q m_{n}$ and $\Delta q o_{n}$, if $<0$, as defined in Eqs. (4) and (5), are used. Thus, $p m_{i}(x, y)$ can be written as:

$p m_{i}(x, y)=\sum_{n} \frac{\Delta q m_{n}}{\left(\Delta q o_{n}+\Delta q m_{n}\right)}$.
This value indicates the fraction of the precipitation in a grid cell that stems from moisture which evaporated inside the ROI. It has to be considered that a small ROI will of course contribute less moisture to any precipitation downwind than a larger ROI.

\section{Results}

\subsection{Residence times}

Forward and backward residence time evaluations were performed only for the Mediterranean basin, in three different vertical layers and for four different time intervals (see Sect. 2.1). Results of the $1 \mathrm{~d}$ residence times evaluations (Fig. 2) show that maxima can be found in the middle of the ROI, indicating a tendency towards stagnation with low wind velocities and/or recirculation. Residence times are clearly higher over the Mediterranean Sea than over adjacent land which is an indicator for recirculation. Forward calculations (Fig. 2) in the $0-1000 \mathrm{~m}$ layer and in the troposphere show similar patterns, as expected for the short transport time. Furthermore, the backward evaluations clearly show that the Alps act as a northern barrier (Sodemann and Zubler, 2010) for the Mediterranean region. Influences from other orographic barriers and local wind systems can be found in the east (Etesians) and in the southwest (Atlas range).

Spatial patterns of 5 day residence times (Fig. 3) are similar to those of the $1 \mathrm{~d}$ residence times. The maximum, a sign towards stagnation, is located in the Tyrrenian Sea between Southern Italy and Turkey. Influence of the Etesian winds on the residence times of air in that area is more clearly visible than in the $1 \mathrm{~d}$ residence times. Inflow from the Black Sea through the Sea of Marmara into the Aegean and outflow to the eastern part of Northern Africa prevails even in the annual means. This leads to lower residence times in the eastern part of the Mediterranean especially on the $5 \mathrm{~d}$ time scale. The overall tendency towards stagnation in certain regions 

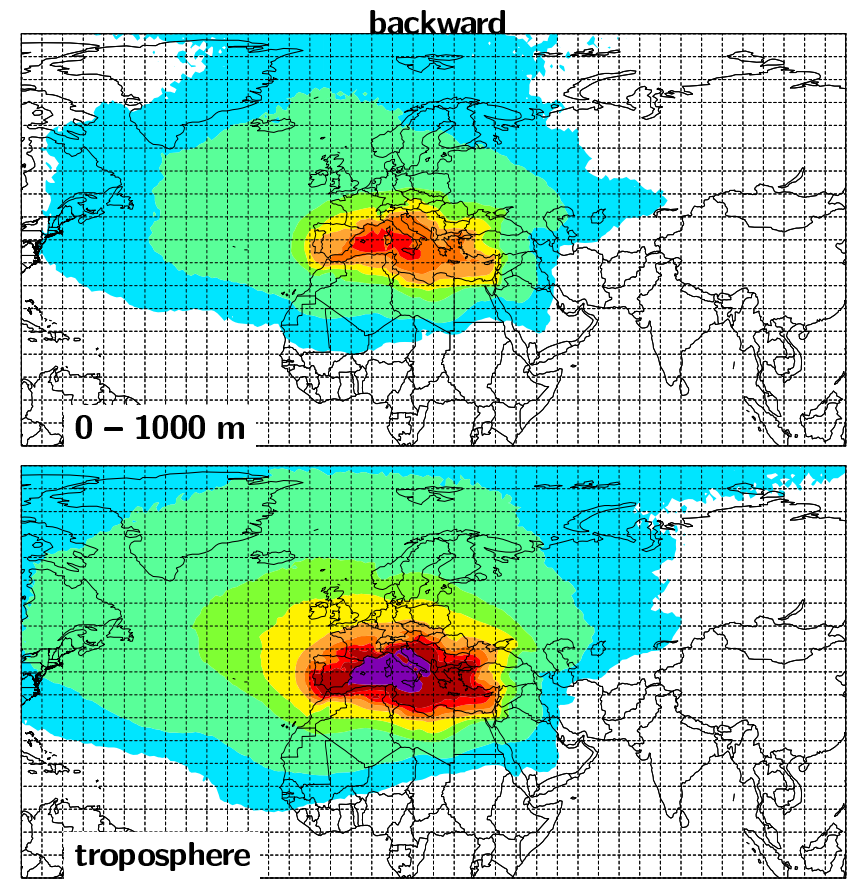

s / day

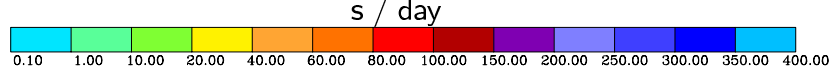

Fig. 3. Five-day residence times.

is still present. Influence of the topography surrounding the Mediterranean basin is clearly recognisable by minima in the atmospheric boundary layer (ABL) residence times over the mountains, where the air partly flows around, and, if going over the mountains, with high velocities. Another example for the topographic influence can be seen in the region of the Atlas mountains where the air is channelled around, also visible in the moisture flux results. The $5 \mathrm{~d}$ residence times show that the Mediterranean air has much more influence on Northeastern Europe than on Northwestern Europe. Contributions into the Red Sea and into North Africa can also be identified as well as influences of the Ahaggar mountains and the Tibesti mountains at the southern borders of the Sahara.

The $30 \mathrm{~d}$ residence times illustrate the position of the Mediterranean in the global circulation. The role of mountains and sea straits becomes even more visible, both in the boundary layer and in the troposphere with the mountainous regions acting as areas of minima of the residence times. These minima are due to the tendency of air flowing around them. Two main transport routes of Mediterranean air can be identified: one enhanced outflow direction through the Strait of Gibraltar and the Red Sea, and one outflow pattern over Mesopotamia. Another transport air stream, inflow or outflow, depending on the season, passes through the Dardanelles. Longer residence times can be found over the Western and Central Mediterranean, both in forward and backward transport calculations, indicating that it is an area with a high recirculation tendency.
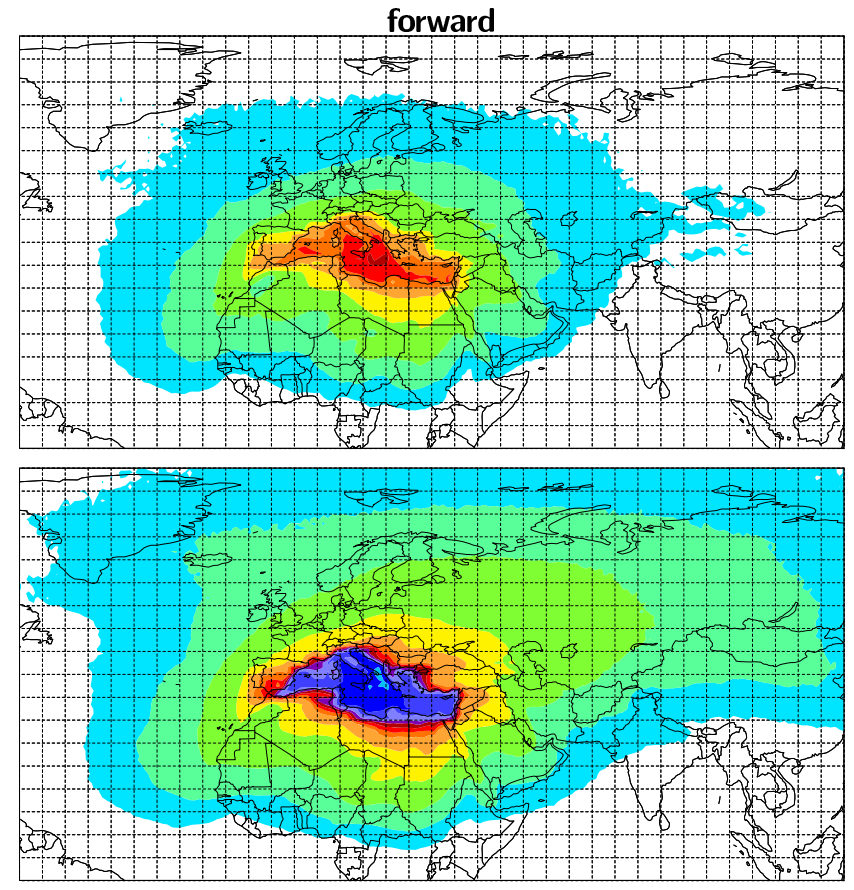

s / day

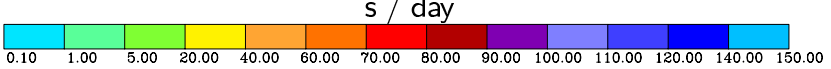

The residence times for the $90 \mathrm{~d}$ intervals (Fig. 4) show clearly the role of the Mediterranean in the global circulation, confirming that it can be called a crossroad of air streams (Lelieveld et al., 2002). As a broad picture, the air enters the Mediterranean mainly from the Northwest, with the $90 \mathrm{~d}$ tropospheric source area consisting of Central and Western Europe and the North Atlantic. High latitudes regions including the Arctic also contribute to the airflow going into the Mediterranean. The outflow is split into two main flows with opposite directions. One follows the Silk Road through Central Asia north of the Tibetan Plateau to the Pacific coast. The other one leads over Northern Africa into the tropical Atlantic towards South America and the Caribbean. Arctic latitudes are very little influenced on this time scale.

\subsection{Stagnation/ventilation}

Results of the $1 \mathrm{~d}$ and $5 \mathrm{~d}$ residence times have already shown tendencies towards stagnation and/or recirculation. One-day stagnation patterns (Fig. 5) show that in winter a dominant streak with strong transport enters the Mediterranean at the Gulf of Lyon, a consequence of large-scale channelling between the Alps and the Pyrenees. It continues through the strait between Tunisia and Sicily and then, in weaker form, passes south of Crete and reaches even the eastern end of the Mediterranean basin. In summer, the dominant region with low stagnation (i.e., strong ventilation) is the Aegean region, where the etesians prevail which are strongest in summer. 

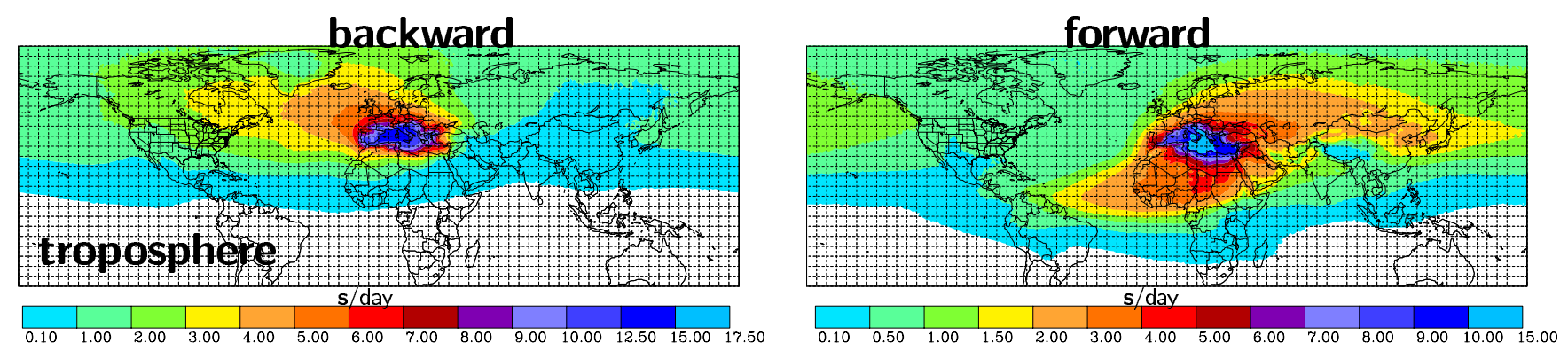

Fig. 4. 90-d residence times.

This flow continues over the whole Mediterranean basin into North Africa. Autumn and spring are a mixture of these two patterns, with much more stagnation over North Africa in autumn than in spring. Areas of stagnation are the Po basin, known to be an area with high air pollution levels (Dosio et al., 2002), the Gulf of Venice, the Atlas mountains, the Sicilian Sea and Turkey. In spring and autumn, the stagnation regions are distributed similarly with low values in the Balearic Sea and Adriatic Sea. Furthermore, one can identify the different topographic influences on the Mediterranean as the mistral in winter, spring and autumn, and the Po basin in winter. Five-day stagnation results (Fig. 6) show that the region with strongest stagnation in summer is the western Mediterranean basin and also the region around Cyprus, which is also present in the other three seasons. Strongest stagnation for land masses can be found over Italy and the Iberian coast; especially the western Mediterranean shows strong stagnation tendencies in summer (Fig. 6). In winter and autumn, stagnation dominates in the easternmost part of the basin. A small spot of stagnation can be found in the southern Adriatic basin in spring.

\subsection{Moisture budget and moisture flux}

Seasonally averaged values of $q m_{i}(x, y)$ (i.e., the fraction of moisture evaporated inside the ROI) were calculated for eight ROIs. Results for the Mediterranean basin as a whole (Fig. 7) show that the highest fractions of moisture are formed over the basin itself with the centre located between the Italian and Hellenic peninsulae. These structures of the moisture fraction $q m_{i}(x, y)$ are present in all four seasons, especially in the three summer months June, July, and August (in the following JJA) where two centres with values between $9 \%$ and $11 \%$ evolve. One centre is located with the maximum at the coast of Tunisia, covering part of the western Mediterranean basin and the central Mediterranean basin. The other one is located between the south cost of Turkey and Cyprus. In autumn and winter, when the evaporation from the sea is large due to high SST compared to air temperature, and advection is strong, $q m_{i}(x, y)$ contributes with fractions of $1.5 \%$ and more to regions outside the Mediterranean and to a lower extend in spring and summer. Contributions of up to $4 \%$, except for summer with lower values of maximum $2.5 \%$, even reach Kazakhstan and European Russia. The coastal areas of Egypt, Libya and Tunisia experience up to 8\% of Mediterranean moisture, showing the relevance of the Mediterranean for these areas.

In the main outflow region following the westerlies in the northeastern part of the Mediterranean, $q m_{i}(x, y)$ shows some influences inland, e.g. in Turkey, the Levant, and Bulgaria with up to $6 \%$ in regions close to the Mediterranean coast and still up to 3\% in the other regions. Mediterranean moisture can be found, although with a very low fraction of less than $0.1 \%$, in the whole Northern Hemisphere. The spatial distribution of $q m_{i}(x, y)$ mainly reflects the predominant transport pathways in the corresponding seasons. Moisture transport to the northeast is strong especially in SON and DJF due to the SST effect. These structures are also visible in the moisture flux analysis (Fig. 11).

Results of the seven sub-basins show similarities with those for the Mediterranean basin as a whole having the absolute maximum near the centres of the ROIs, although on a smaller scale. Outflow from the western Mediterranean basin, ROI 1 (Fig. 8), is directed primarily to the northeast and east contributing to precipitation in these areas. Especially in autumn, contributions of the western Mediterranean basin reach $2-3 \%$, i.e. on the southern slopes of and in the Alpine region. Sodemann and Zubler (2010) showed that the western Mediterranean sector, covering in our definition ROI 1 and ROI 2, plays a major role for Alpine precipitation throughout the seasons, but especially in August and September, again related to ocean evaporation. In summer, we see minor ingestion into the trade wind regime through the Strait of Gibraltar, and into the ITCZ through Algeria and Libya, contributing with up to $8 \%$ to the coast of Algeria and Libya during the summer season. The central Mediterranean, ROI 2 , has only weak influences on regions outside the Mediterranean, partially because the basin is smaller. Although the influences are small, there are still contributions up to $1.5 \%$ close to the northern border of Chad in summer. The main input to the surrounding areas of the basin is into the northeast. ROI 4, the eastern Mediterranean (Fig. 9), 


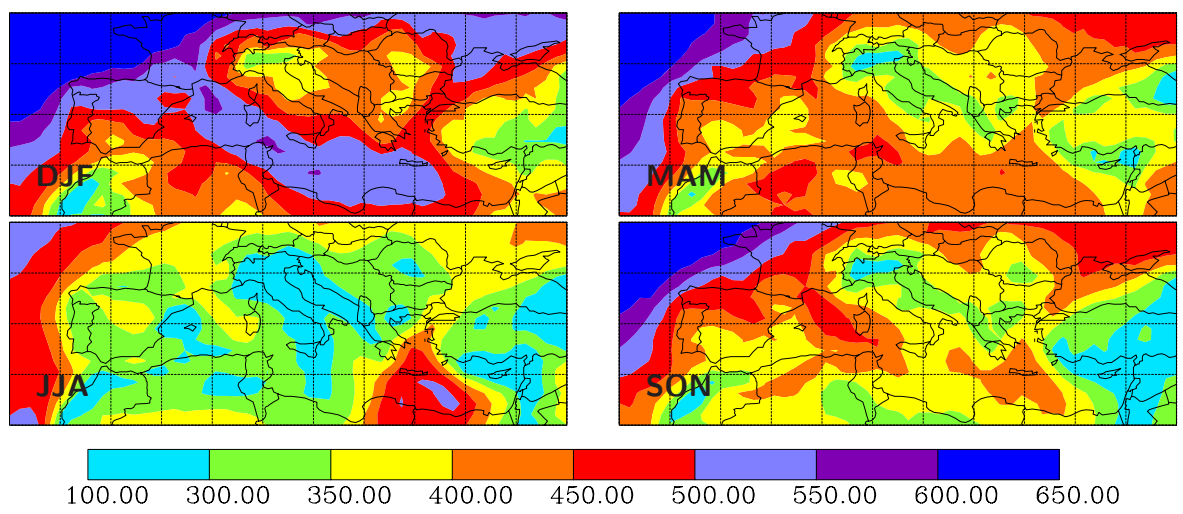

Fig. 5. Seasonally averagered one-day stagnation/ventilation results in the Mediterranean basin, units of km (small values indicate strong stagnation).

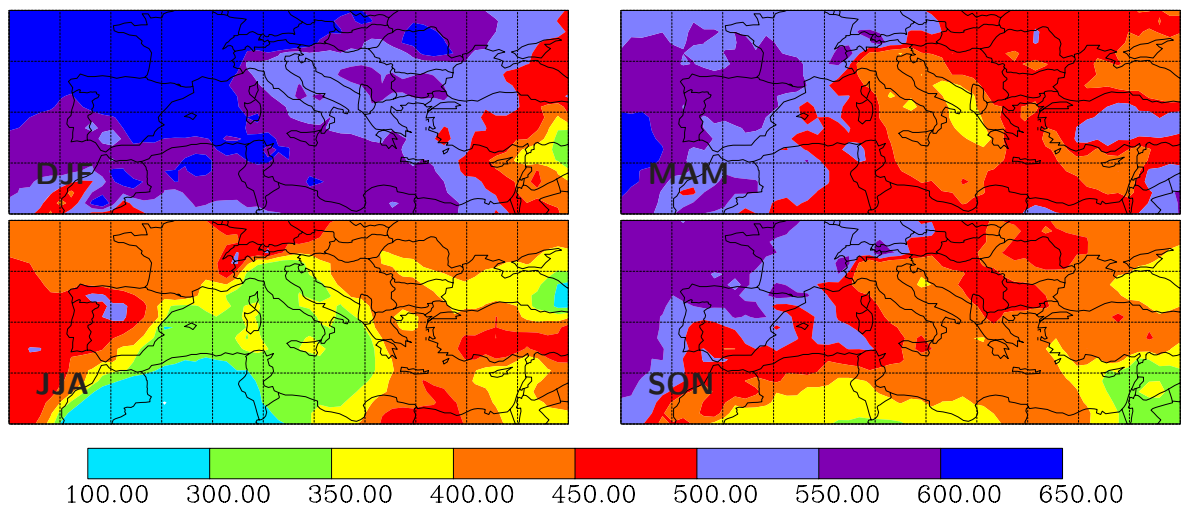

Fig. 6. As Fig. 5 but for five day stagnation/ventilation.

contributes to the region itself and to the Middle East/Levant. Only little influence, below $1.5 \%$, is found in areas further to the east and south. Especially the coastal area of the Levant receives up to $6 \%$ of the Eastern Mediterranean moisture in summer, and $5 \%$ during the other seasons. The outflow of ROI 4 is divided into two main airstreams, one towards the east and one going southward into the ITCZ. Two smaller streams of Mediterranean moisture go in the direction between Egypt and Saudi Arabia, and in the direction of the Persian Gulf, although with small fractions, less than $2 \%$ when reaching the Sea. Influences to the south reach further into North Africa than that of any other major basin, being present in all four seasons and strongest in spring and autumn. Towards the west, no moisture transport can be indentified and only a little is going north.
For the other four small sub-basins effects outside their basin definition do not reach far. The Balearic basin moisture mixing ratio (Fig. 10) contributes $5 \%$ in summer and $1-3 \%$ in the other seasons to air moisture above the Iberian peninsula. This shows that the thermal circulation between the Balearic Sea and the Iberian continent is represented to some extend even in the coarse ECMWF model. Some minor influence of the Balearic basin moisture, between $0.5 \%$ and $1.5 \%$, is found over the Italian peninsula. This influence is strongest in summer while being present, although weaker, in the other seasons, too. The Adriatic basin, ROI 3, shows more influence on the western part of the Balkan than on Italy. A closer look reveals that that the Po basin has a significant moisture fraction of up to $4 \%$ originating in the Adriatic, and the existence of a strong gradient over the western Alps. Up to $4 \%$ in summer and $3 \%$ in the other seasons of Adriatic moisture is present at the Balkan coast. Switzerland receives virtually no Adriatic moisture whereas southern and eastern Austria do, although with a small amount of up to $2 \%$. In the Aegean basin, the contribution of Mediterranean moisture is 

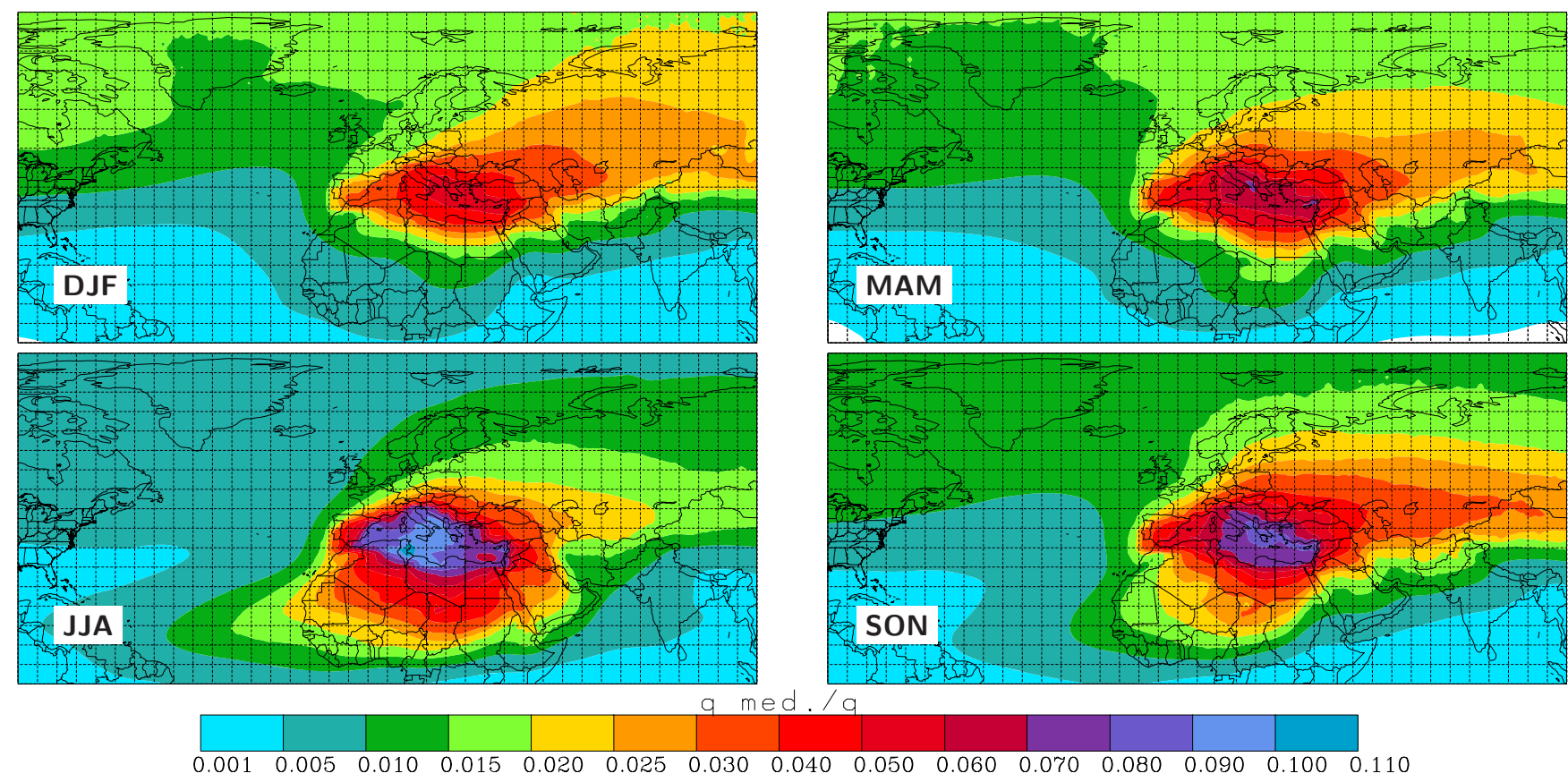

Fig. 7. Seasonal averages of the mixing ratio of the Mediterranean moisture to non-Mediterranean moisture for the Mediterranean basin as a whole.
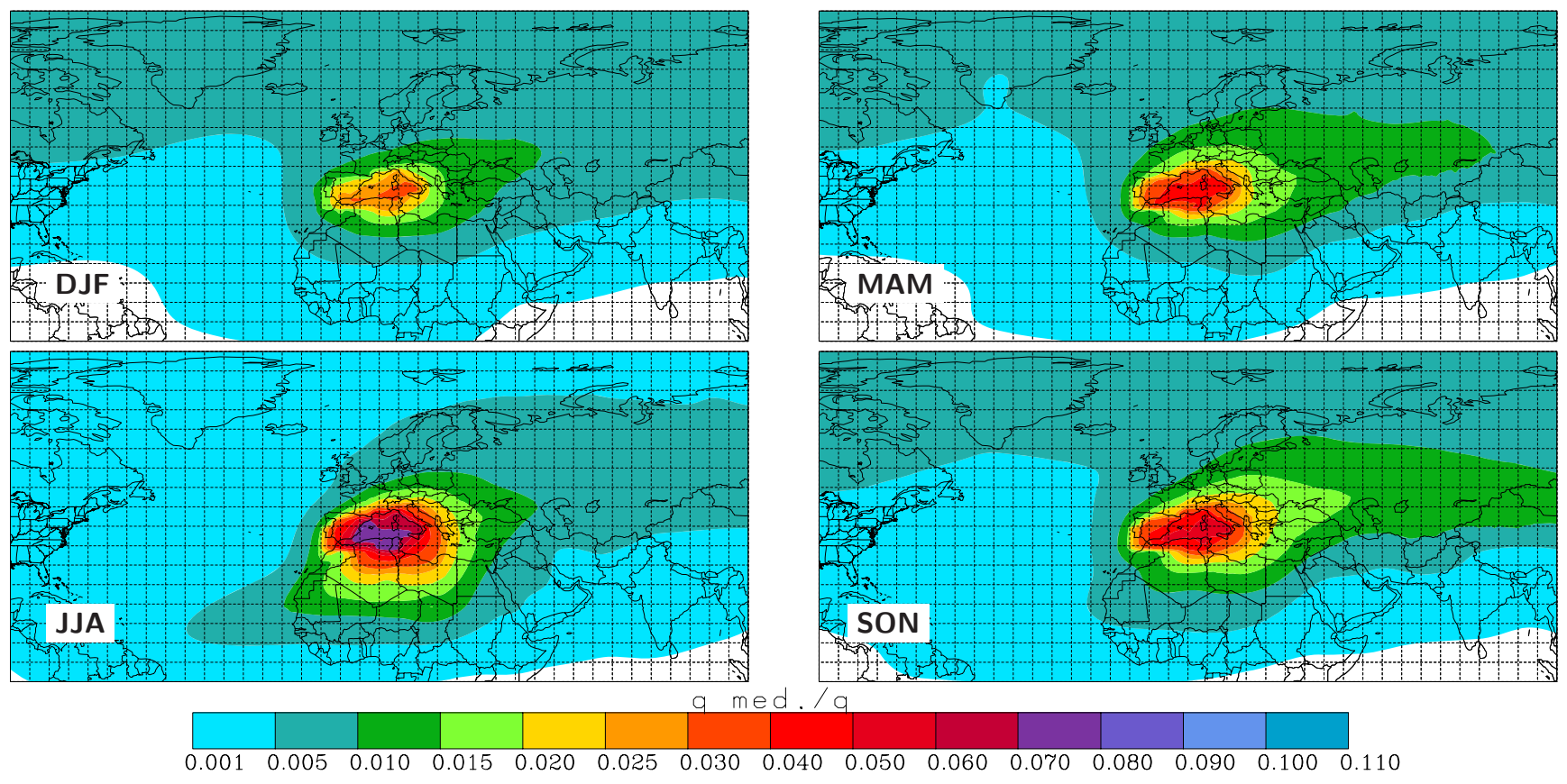

Fig. 8. Same as Fig. 7 (moisture ratio) but for the western Mediterranean basin.

distributed locally with small fractions below $2 \%$ in the area of the Black Sea and Turkey in the northeast in winter and spring, and the Sahara region in summer and autumn. The Cyprus basin has results similar to the Aegean but with flow directions to the east and southeast and higher fractions of
Mediterranean moisture. Fractions of Mediterranean moisture can be found in the region between the Eastern Mediterranean shoreline and Iraq. In contrast to the Aegean, shallow flows of moisture originating from the Cyprus basin are sucked into the atmosphere over Africa. 

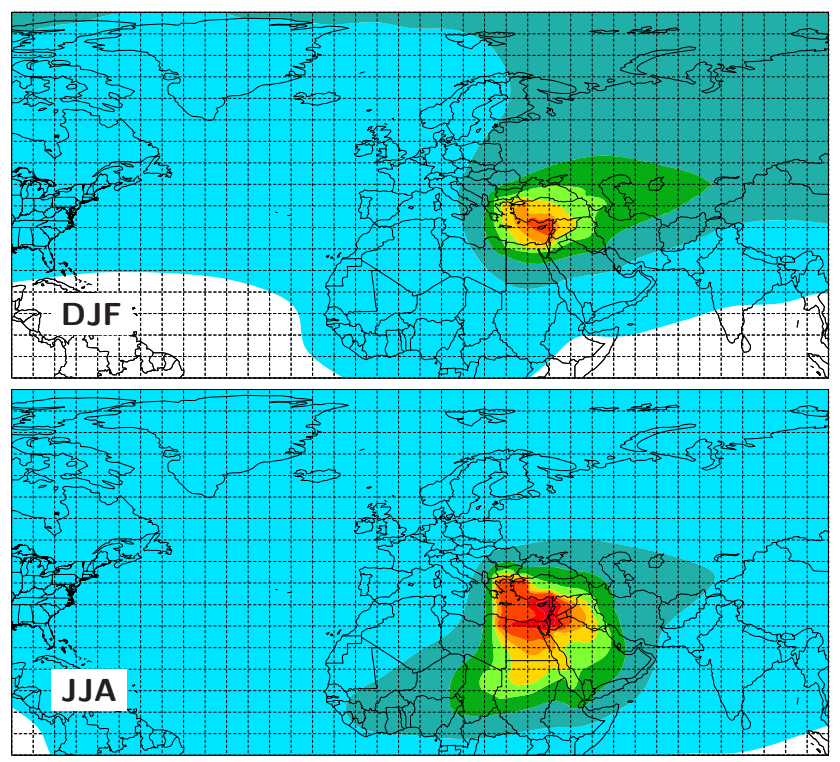
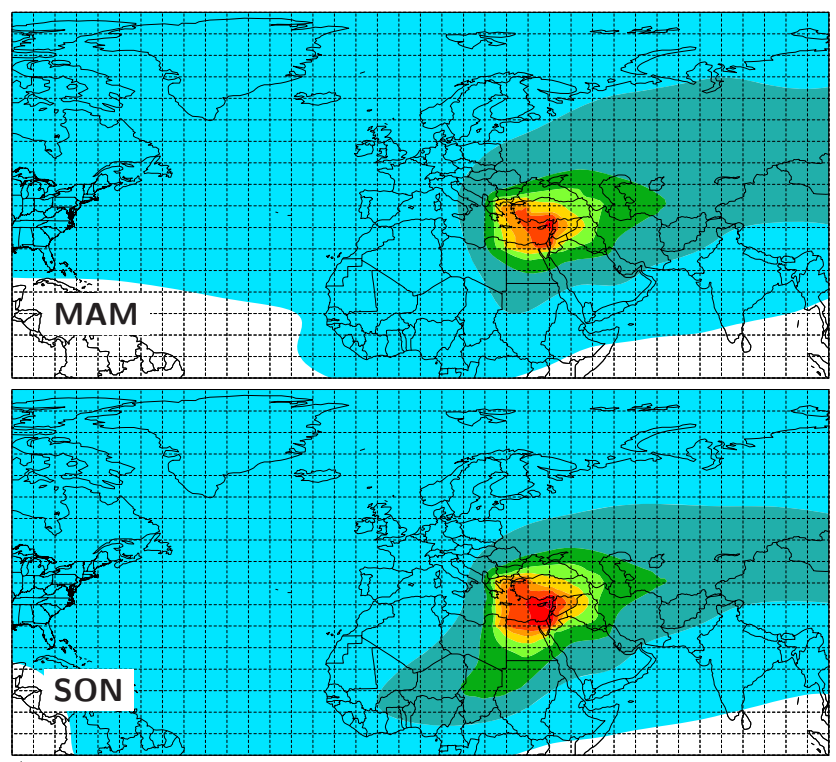

a

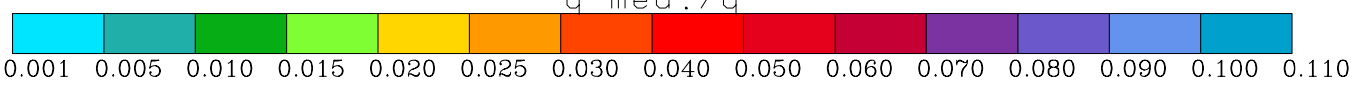

Fig. 9. Same as Fig. 7 (moisture ratio) but for the eastern Mediterranean basin.
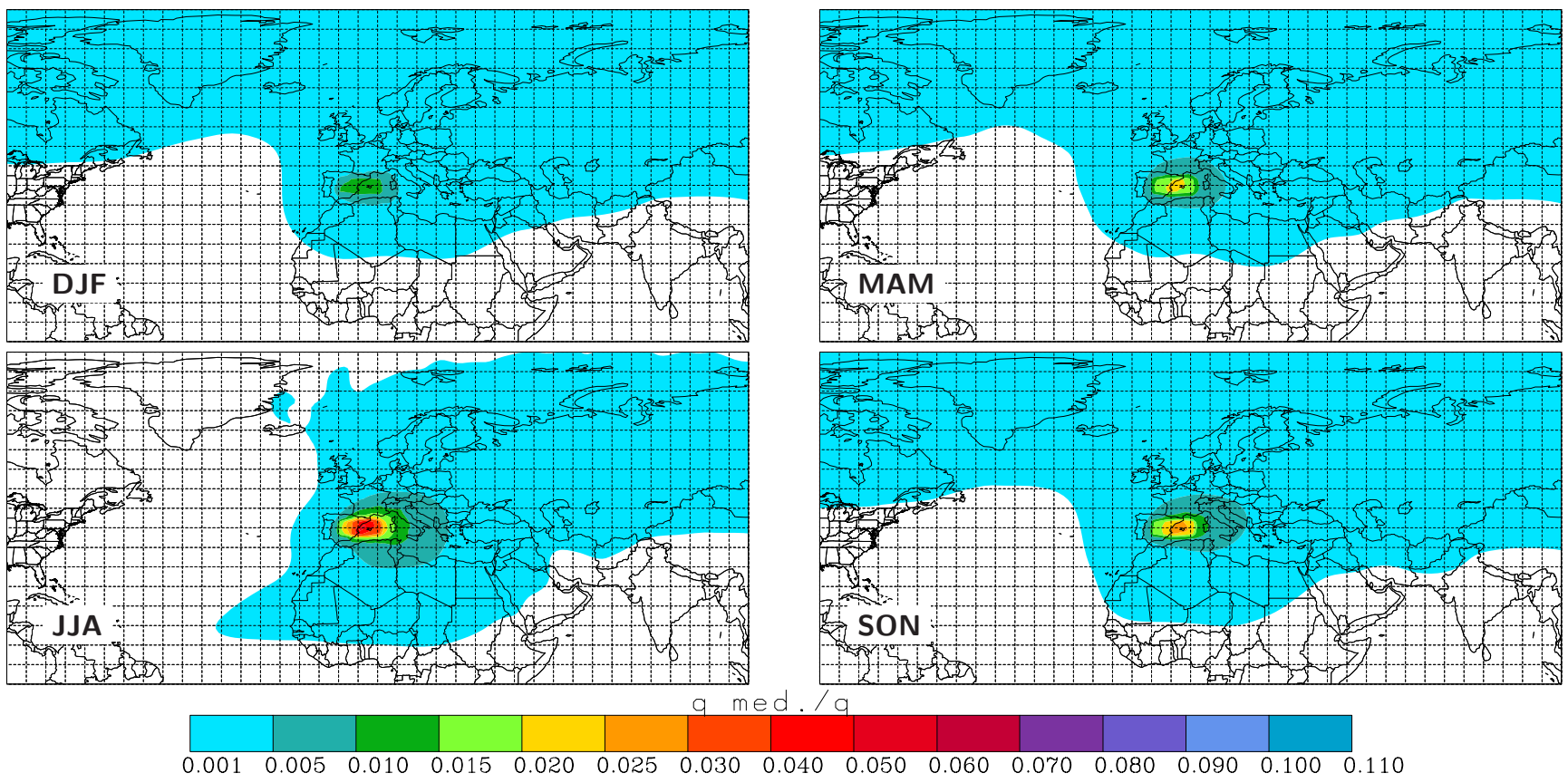

Fig. 10. Same as Fig. 7 (moisture ratio) but for the Balearic basin.

The aforementioned pathways and flows, which could already be seen to a certain extent in the moisture budget evaluations and in the residence time analyses, are clearly identifiable in the moisture flux analysis in Fig. 11 for the 0$20000 \mathrm{~m}$ height interval. Pathways of Mediterranean moisture show ingestions into the ITCZ in all seasons. Strongest flux is found in JJA with three separate flows: one flow over Egypt with $70 \mathrm{~kg}(\mathrm{~m} \mathrm{~s})^{-1}$, the second one over Libya with $125 \mathrm{~kg}\left(\mathrm{~m} \mathrm{~s}^{-1}\right.$, and the third one goes over the Gulf of Gabès and Tunisia with up to $50 \mathrm{~kg}\left(\mathrm{~m} \mathrm{~s}^{-1}\right.$. Outflow into the Red Sea is strongest in JJA with maximum $50 \mathrm{~kg} \mathrm{(m} \mathrm{s})^{-1}$. Mesopotamia recieves up to $125 \mathrm{~kg}\left(\mathrm{~m} \mathrm{~s}^{-1}\right.$ showing the 


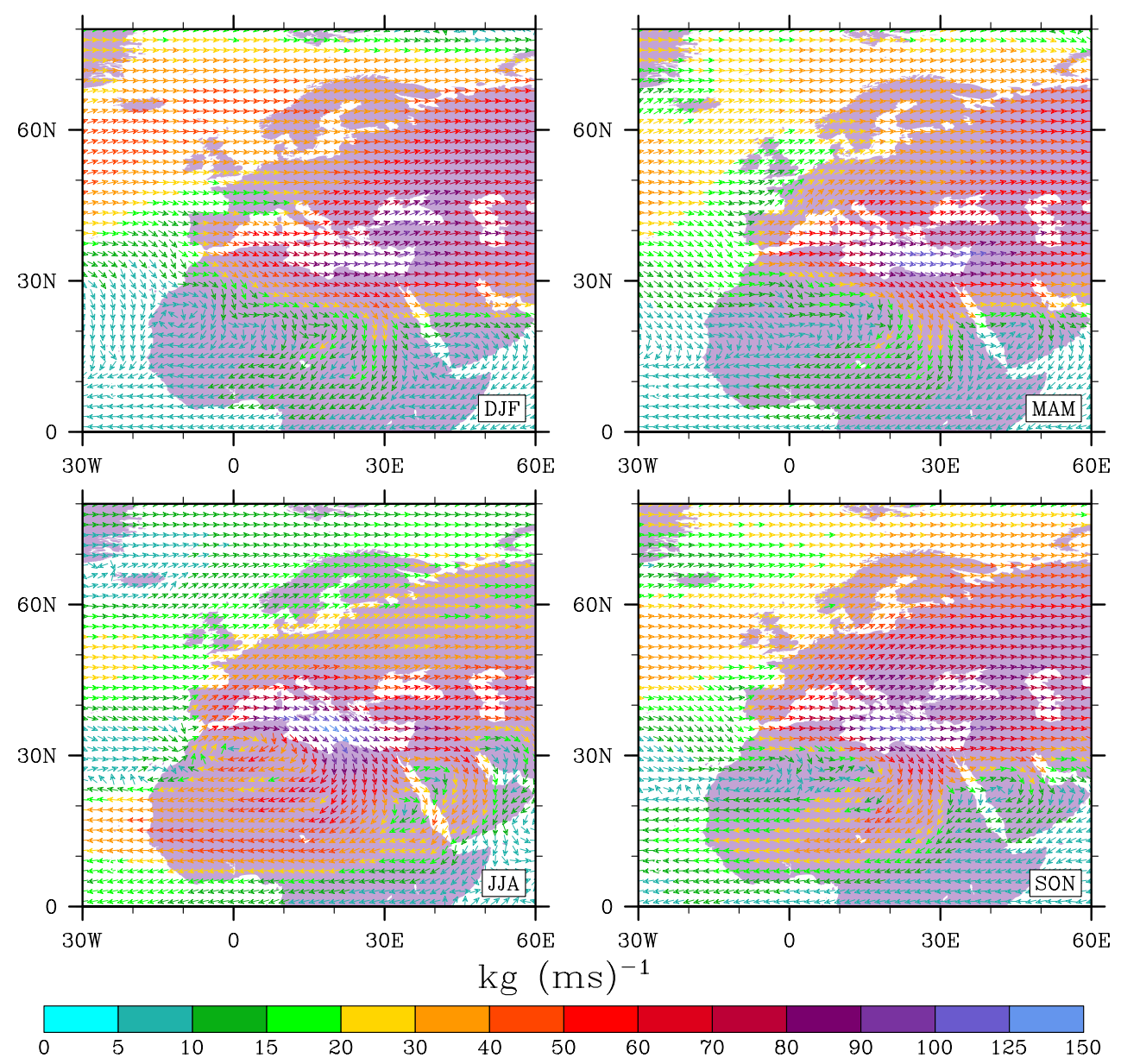

Fig. 11. Calculated moisture flux for particles crossing the Mediterranean basin. For visibility, only every second grid point in $\mathrm{x}$ and $\mathrm{y}$ direction is plotted. Moisture fluxes are shown for the vertical layer below $20000 \mathrm{~m}$.

relevance of the Mediterranean for this region. Over the Arabian peninsula another path into the ITCZ is present. Recirculation tendencies between the Balearics and the southern coast of Spain are visible in the lowest $1000 \mathrm{~m}$ (not shown here). In SON, DJF, and MAM a southerly flow in the Adriatic basin can be found showing the presence of the Sirocco. Results for the 0-20000 m moisture flux evaluations show similar paths as the lowest $1000 \mathrm{~m}$ (not shown) but with higher flux values. Small scale features such as the northerly flow in the Adriatic basin and the recirculation on the southeastern shore of the Iberian peninsula are overlaid whereas the influences of the mountainous regions are still visible.

\subsection{Precipitation budget}

As described in Sect. 2.4, the fraction $\operatorname{pm}_{i}(x, y)$ of the precipitation on a grid cell stemming from moisture evaporated inside the ROI is presented. Spatial and temporal patterns of these precipitation fractions are of course similar to those of the moisture. However, the maxima are clearly higher, and the mimina lower.
In the Mediterranean basin (Fig. 12), the fraction of autochtonous precipitation is at least $14 \%$ throughout the year. In summer it is highest, with values between $20 \%$ and $28 \%$, showing quite sharp edges compared to the other seasons. Seasonal results show, like in the moisture analyses, the influence of the higher SST in autumn compared to spring. In autumn, a maximum of $24 \%$ is located in the eastern Mediterranean. Outflow pathways can be clearly identified, having one strong branch towards the northeast, and a second, weaker one, towards central Africa, especially to the eastern part of the continent. Western North Africa receives less Mediterranean rainwater. Anker et al. (2007) identified in the Jordan Rift Valley six air pathways for precipitation events. They found that the chemical composition of the precipitated water of the western trajectory is associated purely marine thus originating from the Mediterranean Sea. A third maximum is found in the region of Gibraltar, reaching into the trade wind zone in summer, although with a very low fraction. A fourth maximum is found over eastern Central Europe in spring and autumn, probably related to 

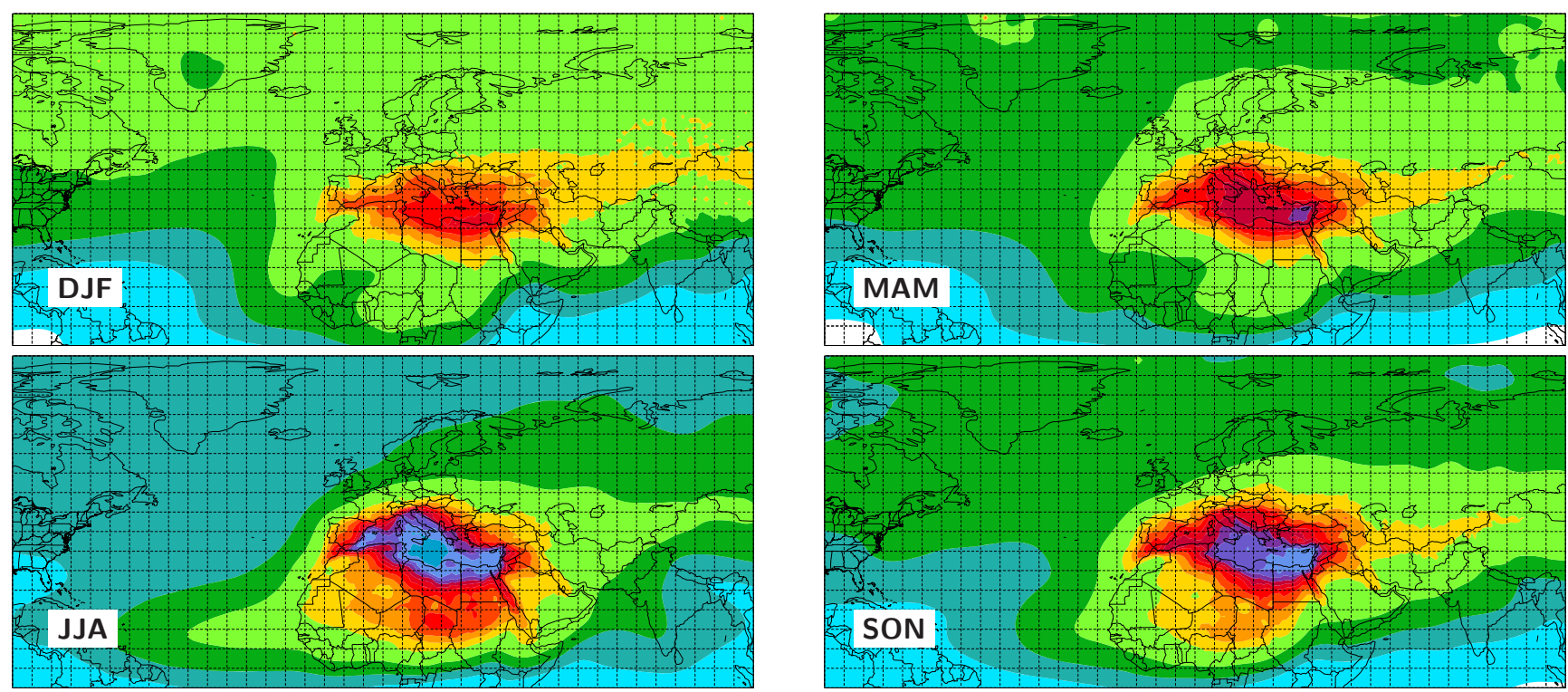

P med

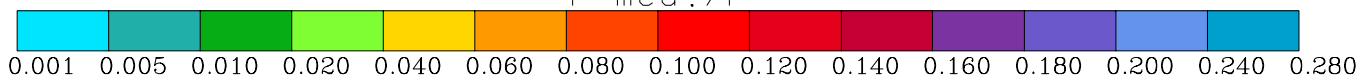

Fig. 12. Fraction of precipitated water that evaporated inside the Mediterranean basin.
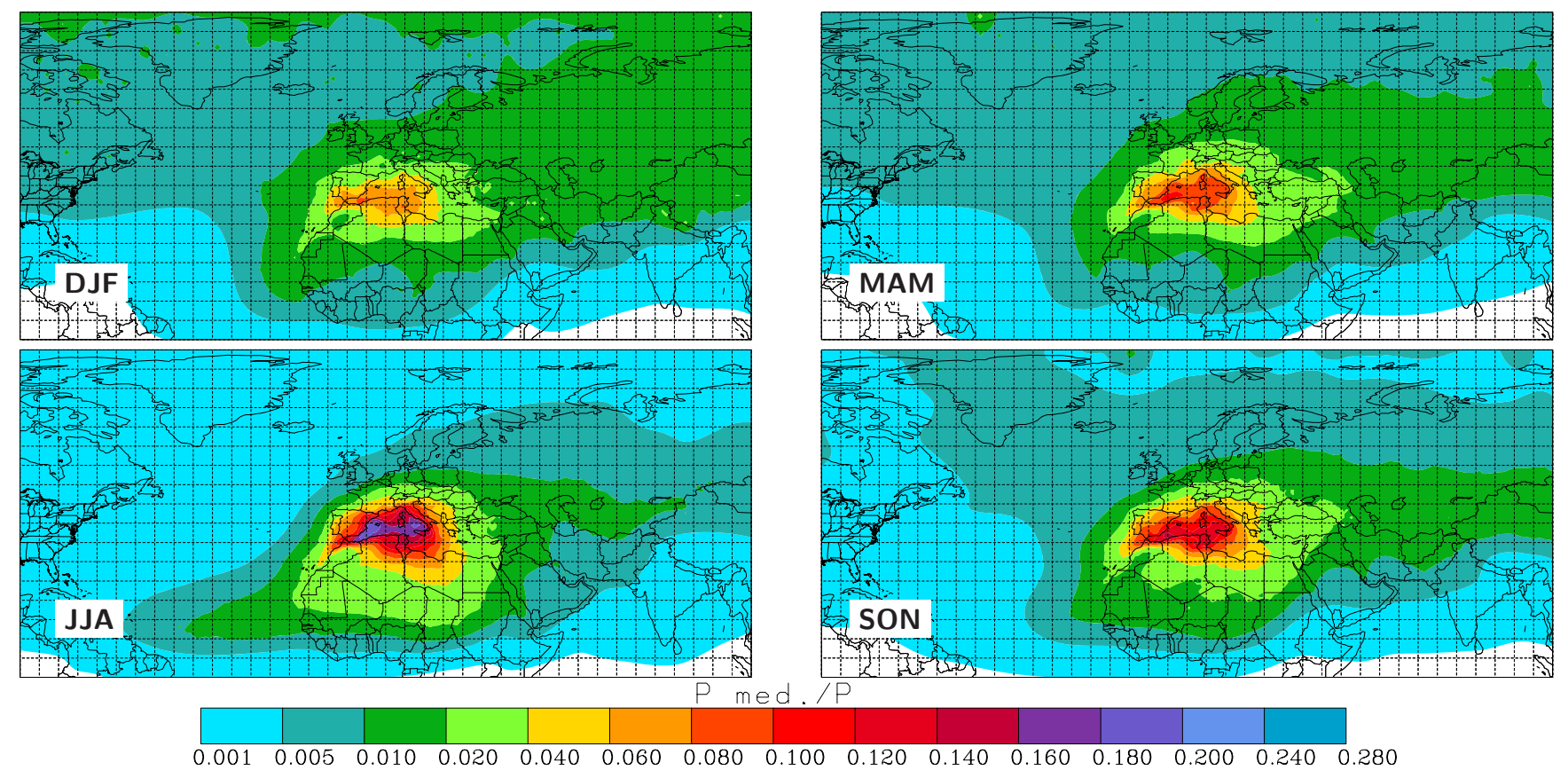

Fig. 13. Same as Fig. 12 (precipitation fraction) but for the western Mediterranean basin.

the well-known higher frequency of meridional circulations in these seasons (Seibert et al., 2006) connected with Vb-like cyclone tracks (Van Bebber, 1891).

The western Mediterranean basin (Fig. 13) contributes to the precipitation at the Algerian and Tunisian coast, the
Balearics and southern Sardinia, especially in summer. In summer, a strong gradient in the north of the basin across the Alpine region is visible. Also a weak transport into the trade wind zone is present. In autumn and winter, when precipitation originating in the western Mediterranean reaches 
into Central Asia, the influences in the north-east are larger than in summer. In the Iberian peninsula, this value is higher in spring, summer, and autumn with up to $12 \%$ of precipitation originating in the Mediterranean. Except for winter, precipitation originating in the Western Mediterranean basin is present over the Adriatic Sea and Italy.

In the Central Mediterranean the influence of precipitation originating in the central Mediterranean basin is changing little over the seasons. In summer and autumn, transport into northern Africa is visible, influence to the northeastern areas is strongest in winter and autumn. Results for the eastern Mediterranean (Fig. 14) show the influence of the basin to the surrounding land mass. During spring, summer, and autumn contributions of the basin to the precipitation in Cyprus are within the range between $16 \%$ and $20 \%$, in winter the contribution is between $4 \%$ and $8 \%$. In summer and autumn the coasts of Egypt, Turkey, Israel, Lebanon, Jordan, and Syria receive $4 \%$ and $12 \%$ of precipitation. Influences of moisture originating in the eastern Mediterranean basin can be found in the precipitation during all seasons reaching far into the land masses with up to $4 \%$, showing distinct transport pathways. Influence of the westerlies are large in winter, spring and autumn. Small contributions can be found in the northwest of Chad in the Tibesti mountains where the precipitation originating in the Mediterranean is below $4 \%$ but still visible in the north, east, and south of the mountain ridges.

Precipitation from moisture evaporated in the Balearic basin influences in summer, the region most strongly between the Balearic islands and the coast of Valencia. Contributions are also present in the Alpine region in southern France, except for winter. Cyclones in the western Mediterranean are known to cause heavy precipitation in these regions, and a substantial fraction of this water comes from the Balearic sub-basin. Transport with the trade winds and with the westerlies is almost absent in the Balearic precipitation budget.

Similar results can be found for the Adriatic basin (Fig. 15) insofar as influences are only local. Fractions are highest in the southern Adriatic Sea, especially in summer. In contrast to moisture, the Po Basin in northern Italy is not a feature for precipitation. Among the land areas, the Dinaric coast has the highest fraction of Adriatic water in precipitation. However, in the main precipitation season (autumn) the fraction is only about $8 \%$, what reveals that sources of atmospheric moisture from more distant areas contribute as well.

The Aegean shows, as in the moisture results, that the precipitation originating from the sub-basin is mostly relevant for the ROI itself. The $2 \%$ zone reaches into Egypt with the trade winds in summer, in winter transport with the westerlies comes close to Crimea. Results for Cyprus show not much difference to the moisture results, although with larger precipitation influence towards Africa.

\section{Conclusions}

Evaluations of the fate and origin of Mediterranean air and atmospheric moisture were carried out based on a Lagrangian transport data set generated with $1^{\circ}$ operational ECMWF data and the Lagrangian particle dispersion model FLEXPART (Stohl et al., 2005). The period 27 October 19991 May 2005 has been investigated. It contains on one hand two extreme events, the heavy Central European flooding event in 2002, and a drought event in 2003. On the other hand it has no extremes of climate modes such as ENSO or NAO, which also influence the conditions in the Mediterranean area. The coarse resolution of the data set is not suitable to make single-year or even one-season analyses, therefore only averages over the full period were analysed.

Residence time analyses, especially of the $30 \mathrm{~d}$ and $90 \mathrm{~d}$ residence times, show that the Mediterranean is a crossroad of air streams (Fig. 16) where the air arrives mainly from the northwest and then is split into two major branches. The first one continues eastwards through Central Asia. The second one bends southwards into North Africa and continues towards southwest over the tropical Atlantic following the trade winds. The source regions for the Mediterranean indicate that the high-latitude regions over the North Atlantic and Canada contribute, while the outflow does not enter any high latitude regions within 90 days. This confirms climatologically the conclusions drawn by Lelieveld et al. (2002) who found similar pathways in summer during their MINOS campaign in 2001.

Another interesting feature is the channeling by mountains and sea straits which is best visible in the $5 \mathrm{~d}$ and $30 \mathrm{~d}$ residence times with minima over the mountains and maxima along the straits, e.g. the strait of Gibraltar, the Red Sea and the Dardanelles as outflow routes. Another channelled outflow route is over Mesopotamia, a lowland between the highlands of Iran and Arabia. The preferred inflow channel is the Gulf of Lyon between the Pyrenees and the Alps. Longer residence times are found over the Western and Central Mediterranean than over the Eastern Mediterranean which is strongly influenced by the Etesian wind crossing the basin.

Stagnation results show a strong seasonal dependency. In winter and spring, the Po Basin, the Adriatic Sea and the region between Turkey and Cyprus show the strongest stagnation. In summer, also the Balearic region and the surroundings of the Italian peninsula have a tendency towards increased stagnation.

Results of the moisture and precipitation analyses show that the Mediterranean basin contributes to the whole Northern Hemisphere, although with a low fraction. Highest fraction of atmospheric moisture and precipitation are located above the Mediterranean Sea itself with a maximum up to $11 \%$ in summer. Sub-basin analyses show that the Western Mediterranean basin has its main influence on the European continent and the Alpine region, a conclusion also drawn by Sodemann and Zubler (2010). Influences of the eastern 

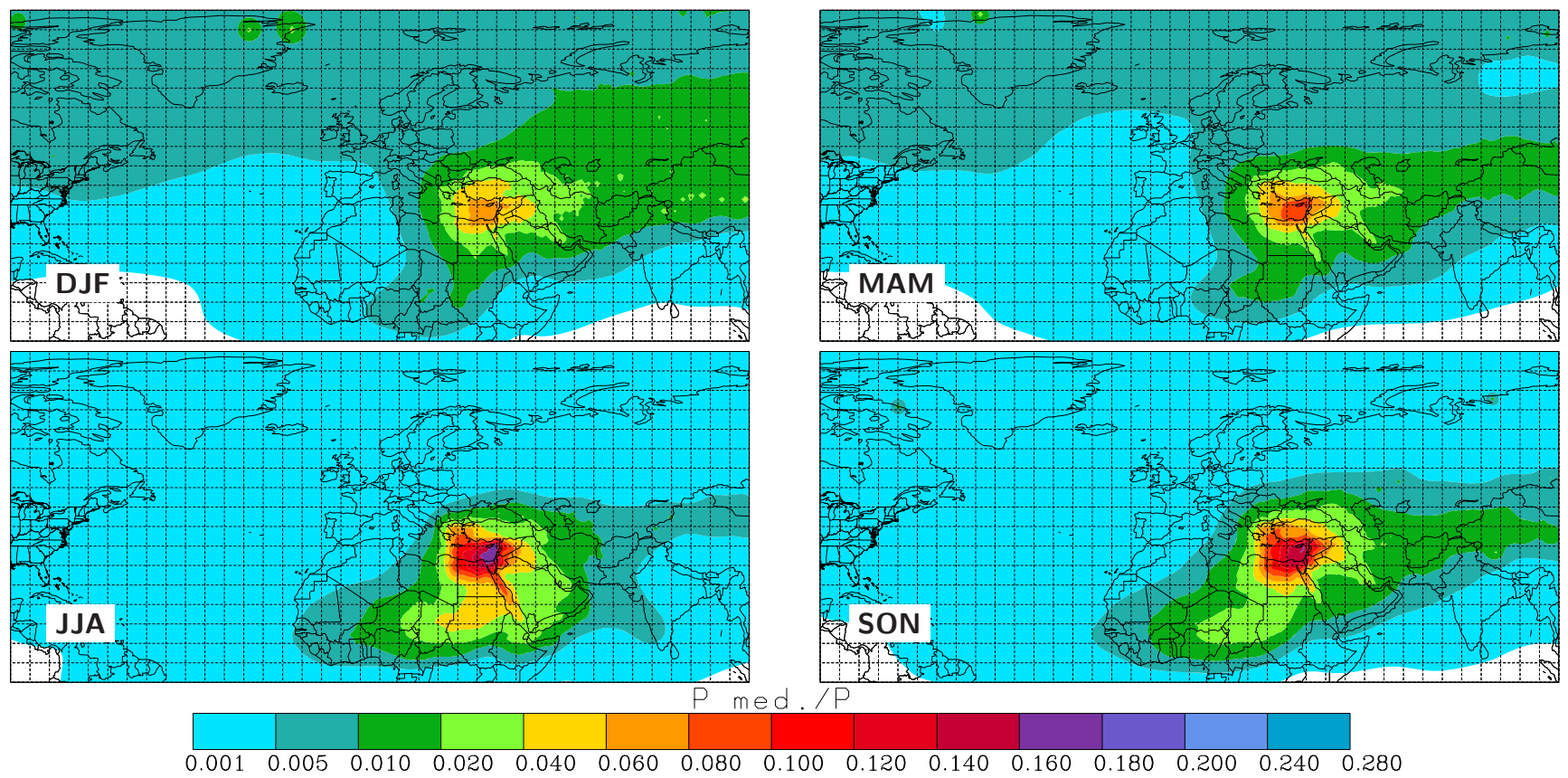

Fig. 14. Same as Fig. 12 (precipitation fraction) but for the eastern Mediterranean basin.
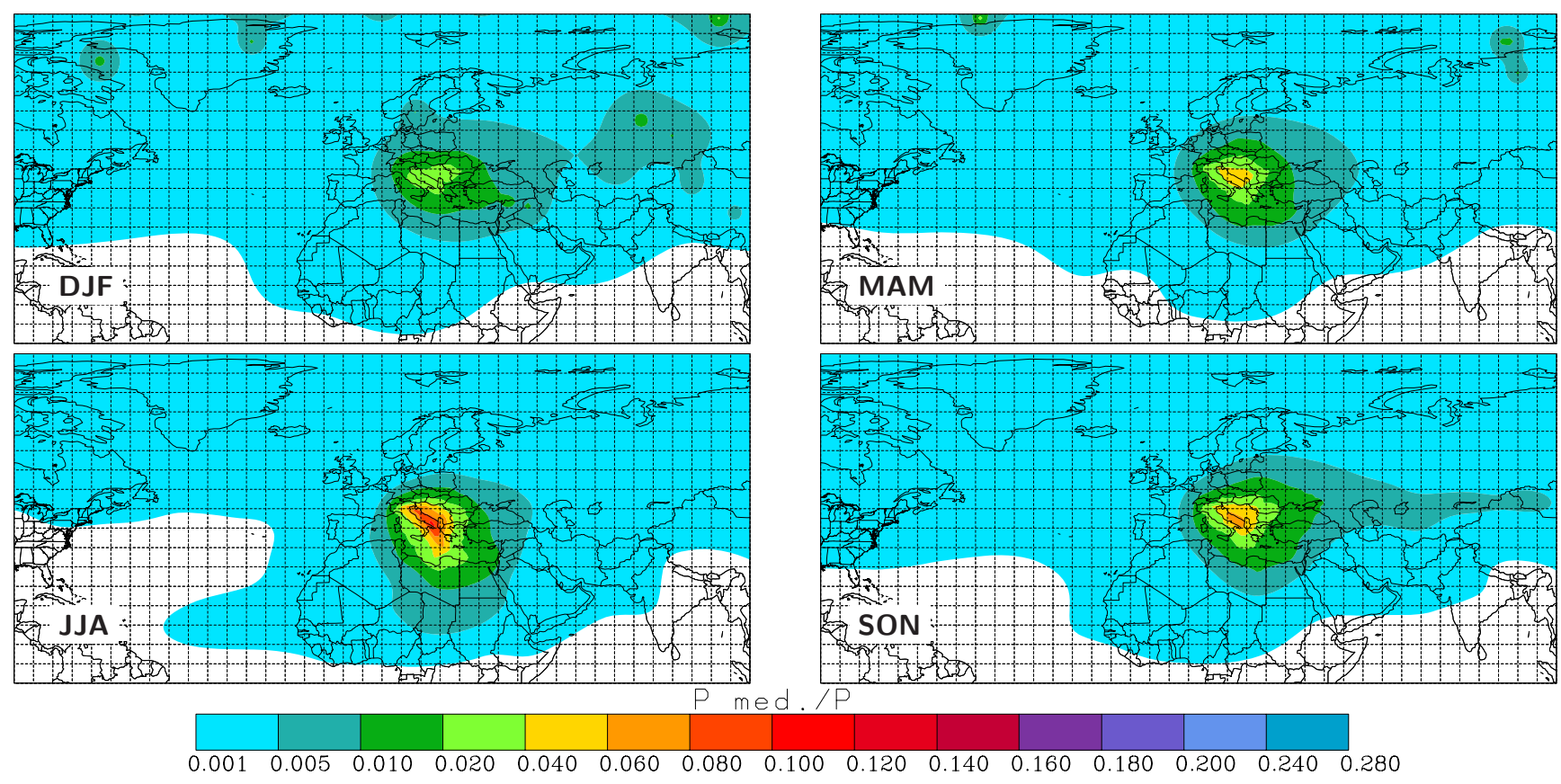

Fig. 15. Same as Fig. 12 (precipitation fraction) but for the Adriatic basin.

Mediterranean basin are mainly in the area of the Middle East and northern Africa. On a smaller scale, as for the Adriatic basin or the Balearic basin, contributions are mainly locally: the Adriatic basin shows its relevance for the Balkan coun- tries, Austria and the Po basin in northern Italy; the Balearic basin shows a significant contribution of up to $5 \%$ of the Mediterranean moisture fraction on the adjacent portion of Spain. An increase of the precipitation fraction can be found 


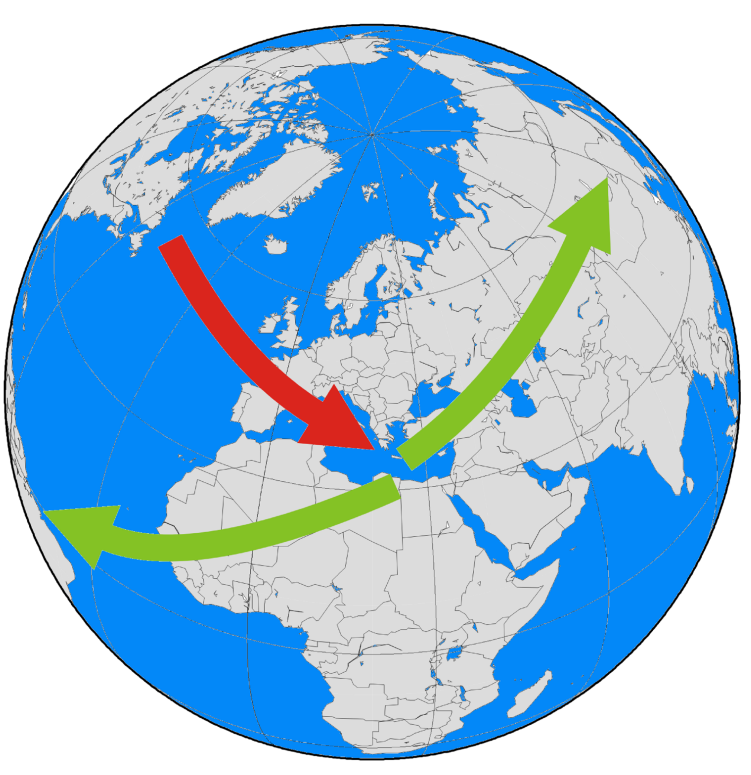

Fig. 16. Air flow crossroads over the Mediterranean basin, red the incoming air, in green the two main outflow patterns.

in autumn when higher SSTs influence the evaporation from the ocean reaching its maximum in November and December (Mariotti et al., 2002).

Mediterranean moisture flux evaluations confirm all the previously mentioned air pathways crossing the Mediterranean basin. Besides the three already mentioned airstreams, some additional streams are present. In summer and autumn, three ingestions paths with up to $60 \mathrm{~kg} \mathrm{(m} \mathrm{s})^{-1}$, into the Intertropical Convergence Zone over Egypt, Libya, and Tunisia are identified, respectively, while in the other seasons the path over Egypt dominates. The influence of the westerlies is present in all seasons, although smaller in summer. Local wind systems, such as the Etesians in summer or the Sirocco in autumn, winter, and spring are especially present in the lowest $1000 \mathrm{~m}$. Another pathway goes into Mesopotamia, showing with up to $125 \mathrm{~kg} \mathrm{(m} \mathrm{s})^{-1}$ the relevance of the Mediterranean basin for this area.

Higher resolved input data as with the new ECMWF resolution plus more particles released would be useful to investigate especially small scale features more deeply. Evaluations of a longer time period would also be useful for a more detailed analysis, especially when analysing in a climatological sense.

Acknowledgements. Special thanks go to Andreas Stohl for providing the trajectory data set. This work was funded by the European Comission's Sixth Framework Programme, Sustainable Development, Global Change and Ecosystems under the project No. 036961, CIRCE Integrated Project-Climate Change and Impact Research: the Mediterranean Environment. We thank an anonymous referee for the helpful comments.

Edited by: H. Wernli

\section{References}

Allwine, K. J. and Whiteman, C. D.: Single-station integral measures of atmospheric stagnation, recirculation and ventilation, Atmos. Environ., 28, 713-721, 1994.

Alpert, P., Baldi, M., Ilani, R., Krichak, S., Price, C., Rodo, X., Saaroni, H., Ziv, B., Kishcha, P., Barkan, J., Mariotti, A., and Xoplaki, E.: Relations between Climate Variability in the Mediterranean Region and the Tropics: ENSO, South Asian and African Monsoons, Hurricanes and Saharan Dust, chap. 2 in the book Mediterranean Climate Variability, 149-177, Elsevier, 2006.

Anker, Y., Flexer, A., Rosenthal, E., and Ganor, E.: Relationship between the origin of precipitation in the Jordan Rift valley and their geochemical composition, J. Geophys. Res., 112, D03306, doi:10.1029/2006JD007517, 2007.

Astitha, M., Kallos, G., and Katsafados, P.: Air pollution modeling in the Mediterranean Region: Analysis and forecasting of episodes, Atmospheric Research, 89, 358-364, doi:10.1016/j. atmosres.2008.03.006, 2008.

Bethoux, J. P. and Gentili, B.: Functioning of the Mediterranean Sea: Past and present changes related to freshwater input and climatic change, J. Mar. Syst., 20, 33-47, 1999.

Brubaker, K. L., Entekhabi, D., and Eagleson, P.: Estimation of continental precipitation recycling, J. Climate, 6, 1077-1089, 1993.

Dosio, A., Galmarini, S., and Graziani, G.: Simulation of the circulation and related photochemical ozone dispersion in the Po plains (northern Italy): Comparison with the observations of a measuring campaign, J. Geophys. Res., 107(D22), 8189, doi:10.1029/2000JD000046, 2002.

Drobinski, P. and Ducrocq, V., eds.: HYMEX: White Book, http: //www.hymex.org/global/documents/WB_1.3.2.pdf, 2008.

Drumond, A., R., N., Gimeno, L., and Ambrizzi, T.: A Lagrangian identification of major sources of moisture over central Brazil and La Plata basin, J. Geophys. Res., 113, D14128, doi:10.1028/2007JD009547, 2008.

Eckhardt, S., Stohl, A., Wernli, H., James, P., Forster, C., and Spichtinger, N.: A 15-year climatology of warm conveyor belts, J. Climate, 17, 218-237, 2004.

Eltahir, E. A. B. and Bras, R. L.: Precipitation recycling, Rev. Geophys., 34, 367-378, 1996.

Eshel, G. and Farrel, B. F.: Mechanisms of Eastern Mediterranean rainfall variability, J. Atmos Sci., 57, 3219-3232, 2000.

Gibelin, A. L. and Deque, M.: Anthropogenic climate change over the Mediterranean region simulated by a global variable resolution model, Clim. Dyn., 20, 237-339, 2003.

Giorgi, F.: Climate change hot-spots, Geophys. Res. Lett., 33, L08707, doi:10.1029/2006GL025734, 2006.

Hurrell, J.: Decadal trends in the North Atlantic Oscillation: Regional temperatures and precipitation, Science, 269, 676-679, 1995.

Hurrell, J. W.: Influence of variations in extratropical wintertime teleconnections on Northern Hemisphere temperature, Geophys. Res. Lett., 23, 665-668, 1996.

James, P., Stohl, A., Spichtinger, N., Eckhardt, S., and Forster, C.: Climatological aspects of the extreme European rainfall of August 2002 and a trajectory method for estimating the associated evaporative source regions, Nat. Hazards Earth Syst. Sci., 4, $733-$ 746, doi:10.5194/nhess-4-733-2004, 2004.

Kallos, G., Kotroni, V., Lagouvardos, K., and Papadopoulos, A.: On the Long-Range transport of air pollutants from Europe to Africa, 
Geophys. Res. Lett., 25, 619-622, doi:10.1029/97GL03319, 1998.

Kallos, G., Astitha, M., Katsafados, P., and Spyrou, C.: Long-Rrnge transport of anthropogenically and naturally produced particulate matter in the Mediterranean and North Atlantic: current state of knowledge, J. Appl. Meteor. Climatol., 46, 1230-1251, 2007.

Krichak, S. O. and Alpert, P.: Decadal trends in the east Atlanticwest Russia pattern and Mediterranean precipitation, Int J. Climatol., 25, 183-192, 2005.

Krichak, S. O., Kishcha, P., and Alpert, P.: Decadal trends of main Eurasian oscillations and the Eastern Mediterranean precipitation, Theor. Appl. Climatol., 72, 209-220, 2002.

Lazaridis, M., Eleftheriadis, K., Smolik, J., Colbeck, I., Kallos, G., Drossinos, Y., Zdimal, V., Vecera, Z., Mihalopoulos, N., Mikuska, P., Bryant, C., Housiadas, C., Spyridaki, A., Astitha, M., and Havranek, V.: Dynamics of fine particles and photooxidants in the Eastern Mediterranean (SUB-AERO), Atmospheric Environment, 40, 6214-6228, doi:10.1016/j.atmosenv. 2005.06.050, 2006.

Lelieveld, J., Berresheim, H., Borrmann, S., Crutzen, P. J., Dentener, F. J., Fischer, H., Feichter, J., Flatau, P. J., Heland, J., Holzinger, R., Korrmann, R., Lawrence, M. G., Levin, Z., Markowicz, K. M., Mihalopoulos, N., Minikin, A., Ramanathan, V., de Reus, M., Roelofs, G. J., Scheeren, H. A., Sciare, J., Schlager, H., Schultz, M., Siegmund, P., Steil, B., Stephanou, E. G., Stier, P., Traub, M., Warneke, C., Williams, J., and Ziereis, H.: Global air pollution crossroads over the Mediterranean, Science, 298, 794-799, 2002.

Lionello, P., Malanotte-Rizzoli, P., Alpert, P., Artale, V., Boscolo, R., Garcia-Herrera, R., Kull, C., Li, L., Luterbacher, J., Oguz, T., May, W., Planton, S., Rodo, X., Theocharis, A., Trigo, R., Tsimplis, M., and Ulbrich, U.: MEDCLIVAR: Mediterranean CLImate VARiability and predictability project, PAGES News/CLIVAR Exchanges, 13, 3-5, 2006.

Luterbacher, J. and Xoplaki, E.: 500-year Winter Temperature and Precipitation Variability over the Mediterranean area and its Connection to the Large-scale Atmospheric Circulation., chap. 4, in the book Mediterranean Climate: Variability and Trends., 133153, Springer Verlag, Berlin, New York, 2003.

Mariotti, A., Struglia, M. V., Zeng, N., and Lau, K. M.: The hydrological cycle in the Mediterranean region and implications for the water budget of the Mediterranean Sea, J. Climate, 15, 16741690, 2002.

Mihalopoulos, N. and de Reus, M. (eds.): Special Issue "Mediterranean intensive oxidant study (MINOS 2001)", Atmos. Chem. Phys., http://www.atmos-chem-phys.net/special_issue4. html, 2003.

Millán, M., Artiñano, B., Alonso, L., Castro, M., Fernandez-Patier, R., and Goberna, J.: Mesometeorological cycles of air pollution in the Iberian Peninsula (MECAPIP), Tech. Rep. 44, Air Pollution Research Report, European Comission, 1992.

Millán, M., Salvador, R., Mantilla, E., and nano, B. A.: Meteorology and photochemical air pollution in Southern Europe: Experimental results from EC research projects, Atmospheric Environment, 30, 1909-1924, doi:10.1016/1352-2310(95)00220-0, 1996.

Millán, M., Sanz, M. J., Salvador, R., and Mantilla, E.: Atmospheric dynamics and ozone cycles related to nitrogen deposition in the western Mediterranean, Environmental Pollution, 118, 167
- 186, doi:10.1016/S0269-7491(01)00311-6, 2002.

Millán, M. M., Salvador, R., Mantilla, E., and Kallos, G.: Photooxidant dynamics in the Mediterranean basin in summer: Results from European research projects, J. Geophys. Res., 102, 88118823, 1997.

Newell, R. E. and Evans, M. J.: Seasonal changes in pollutant transport to the North Pacific: the relative importance of Asian and European sources, Geophys. Res. Lett., 27, 2509-2512, 2000.

Newell, R. E., Newell, N. E., Zhu, Y., and Scott, C.: Tropospheric rivers? A pilot study, Geophys. Res. Lett., 19, 2401-2404, 1992.

Nieto, R. and Gimeno, L.: Atmospheric transport towards the Iberian Peninsula in the 3- to 10-day range. Sources of middlelived pollutants and aerosols., ScientificWorldJournal, 10, 10411047, 2006.

Nieto, R., Gimeno, L., and Trigo, R.: A Lagrangian identification of major sources of Sahel moisture, Geophys. Res. Lett., 3, L18707, doi:10.1029/2006GL027232, 2006.

Nieto, R., Gimeno, L., Gallego, D., and Trigo, R.: Identification of major sources of moisture and precipitation over Iceland, Meteor. Z., 16, 37-44, 2007.

Nieto, R., Gallego, D., Trigo, R., Ribera, P., and Gimeno, L.: Dynamic identification of moisture sources in the Orinoco Basin in Equatorial South America, Hydrol. Sci., 53, 602-617, 2008.

Rodo, X., Baert, E., and Comin, F. A.: Variations in seasonal rainfall in southern Europe during present century: Relationships with the North Atlantic Oscillation and the El Niño Southern Oscillation, Climate Dyn., 13, 275-284, 1997.

Salvador, R., Millan, M., Mantilla, E., and Baldasano, J. M.: Mesoscale modelling of atmospheric processes over the western Mediterranean area during summer, Int. J. Environ. Pollut., 8, 513-529, 1997.

Seibert, P., Frank, A., and Formayer, H.: Synoptic and regional patterns of heavy precipitation in Austria, Theor. Appl. Climatol., 87, 139-153, doi:10.1007/s00704-006-0198-8, 2006.

Seibert, P., Schicker, I., and Radanovics, R.: Data base of moisture balance for selected airsheds, Climate Change and Impact Research: The Mediterranean Basin (CIRCE), EU Sixth Framework Programme, http://www.boku.ac.at/met/envmet/files/circe/ CIRCE_Deliverable_431.pdf, 2009.

Sodemann, H.: Tropospheric transport of water vapour: Lagrangian and Eulerian perspectives, Ph.D. thesis, ETH Zurich, Logos Verlag, Berlin, 230 pp, ISBN 3-8325-1384-1, 2006.

Sodemann, H. and Zubler, E.: Seasonality and inter-annual variability of the moisture sources for Alpine precipitation during 19952002, Int. J. Climatol., 30, 947-961, doi:10.1002/joc.1932, 2010.

Sodemann, H., Masson-Delmotte, V., Schwierz, C., Vinther, B. M., and Wernli, H.: Inter-annual variability of Greenland winter precipitation sources: 2. Effects of North Atlantic Oscillation variability on stable isotopes in precipitation., J. Geophys. Res., 113, D12111, doi:10.1029/2007JD009416, 2008b.

Sodemann, H., Schwierz, C., and Wernli, H.: Inter-annual variability of Greenland winter precipitation sources: 1. Lagrangian moisture diagnostic and North Atlantic Oscillation influence., J. Geophys. Res., 113, D03107, doi:10.1029/2007JD008503, 2008a.

Stohl, A.: Characteristics of atmospheric transport into the Arctic troposphere, J. Geophys. Res., 111, D11306, doi:10.1029/ 2005JD006888, 2006.

Stohl, A. and James, P.: A Lagrangian analysis of the atmospheric 
branch of the global water cycle: 1 . Method description, validation, and demonstration for the flooding in Central Europe, J. Hydrometeor., 5, 656-678, 2004.

Stohl, A. and James, P.: A Lagrangian analysis of the atmospheric branch of the global water cycle: 2. Earth's river catchments, ocean basins, and moisture transports between them, J. Hydrometeor., 6, 961-984, 2005.

Stohl, A., Hittenberger, M., and Wotawa, G.: Validation of the Lagrangian particle dispersion model FLEXPART against large scale tracer experiments, Atmos. Environ., 32, 4245-4264, 1998.

Stohl, A., Eckhardt, S., Forster, C., James, P., and Spichtinger, N.: On the pathways and timescales of intercontinental air pollution transport, J. Geophys. Res., 107, 4684, doi:10.1029/ 2001JD001396, 2002.

Stohl, A., Forster, C., Frank, A., Seibert, P., and Wotawa, G.: Technical note: The Lagrangian particle dispersion model FLEXPART version 6.2, Atmos. Chem. Phys., 5, 2461-2474, doi:10.5194/acp-5-2461-2005, 2005.
Van Bebber, W.: Die Zugstraßen der barometrischen Minima nach den Bahnenkarten der Deutschen Seewarte für den Zeitraum von 1875-1890, Meteor. Z., 8, 361-366, 1891.

Ward, M. N.: Diagnosis and short-lead predictions of summer rainfall in tropical North Africa at interannual and multidecadal timescales, J. Climate, 11, 3167-3191, 1998.

Weaver, A. J., Bitz, C. M., Fanning, A. F., and Holland, M. M.: Thermohaline circulation: High-latitude phenomena and the difference between the Pacific and Atlantic, Ann. Rev. Earth Planet. Sci., 27, 231-285, 1999.

Xoplaki, E., González-Rouco, J. F., Luterbacher, J., and Wanner, H.: Mediterranean summer air temperature variability and its connection to the large-scale atmospheric circulation and SSTs, Clim. Dynam., 20, 723-739, 2003.

Zhu, Y. and Newell, R. E.: A proposed algorithm for moisture fluxes from atmospheric rivers, Mon. Weather Rev., 126, 725$735,1998$. 